\title{
Prebiotic experiments simulating hydrothermal vents: Influence of olivine in the decomposition of simple carboxylic acids
}

\author{
Experimentos prebióticos que simulan respiraderos hidrotermales: influencia del olivino \\ en la descomposición de ácidos carboxílicos simples
}

\author{
Lucía A. González-López ${ }^{1}$, María Colín-García ${ }^{2, *}$, Adriana Meléndez-López², Jorge Gruz-Castañeda ${ }^{3}$, \\ Alicia Negrón-Mendoza ${ }^{3}$
}

${ }^{1}$ Posgrado en Ciencias de la Tierra, Universidad Nacional Autónoma de México, Cd. Universitaria, Coyoacán, 04510, CDMX, Mexico.

${ }^{2}$ Instituto de Geología, Universidad Nacional Autónoma de México, Circuito Exterior s/n, Cd. Universitaria, Coyoacán, 04510, CDMX, Mexico.

${ }^{3}$ Instituto de Ciencias Nucleares, Universidad Nacional Autónoma de México, Circuito Exterior S/N, Cd. Universitaria, Coyoacán, 04510, GDMX, Mexico.

* Corresponding author: (M. Colín-García) mcolin@geologia.unam.mx

\section{How to cite this article:}

González-López, L.A., Colín-García, M., Meléndez-López, A., Cruz-Castañeda, J., Negrón-Mendoza, A., 2021, Prebiotic experiments simulating hydrothermal vents: Influence of olivine in the decomposition of simple carboxylic acids: Boletín de la Sociedad Geológica Mexicana, 73 (3), A291220. http://dx.doi.org/10.18268/ BSGM2021v73n3a291220

Manuscript received: September 19, 2020 Corrected manuscript received: December 22, 2020 Manuscript accepted: December 30, 2020

Peer Reviewing under the responsibility of Universidad Nacional Autónoma de México.

This is an open access article under the CC BY-NC-SA license(https://creativecommons.org/licenses/by-nc-sa/4.0/)
ABSTRACT

Hydrothermal systems have been proposed as keen environments on the early Earth where chemical evolution processes could have occurred. The presence of minerals and a continuous energy flux stand out among the most remarkable conditions in such environments. In this research the decomposition of two organic acids was studied. Ionizing radiation and thermal energy were the sources selected for decomposition tests, as both are naturally present on hydrothermal systems and probably, they were present on early Earth. Radiation could come from unstable elements in minerals, and heat is the most abundant energy source in hydrothermal systems. As minerals play a key role in prebiotic chemistry experiments and are an essential component on hydrothermal environments, the role of olivine in decomposition was tested. Results indicate that both organic acids highly decomposed when irradiated or heated. Radiation is more efficient than heating in decomposing the carboxylic acids and forming other carboxylic acids. Interestingly, the occurrence of olivine affects decomposition on both heated and irradiated samples, as both the rate of decomposition, and the amount and type of products vary compared with experiments without the mineral. The formation of other carboxylic acids was followed in all samples. Succinic, tricarballilic, citric and carboxisuccinic acids were detected in radiolysis experiments of acetic acid. The radiolysis of formic acid produced oxalic and tartronic. The heating of acetic acid solutions formed succinic, tricarballilic, citric and carboxisuccinic acids. However, the heating of formic acids only generated oxalic acid. The presence of olivine affected the amount and type of carboxylic acids formed in radiation and heating experiments. Natural hydrothermal systems are complex environments and many variables are present in them. Our results reinforce the idea that a combination of variables is necessary to better simulate these environments in prebiotic chemistry experiments. All variables could have affected the prebiotic chemical reactions; and hence, the role of hydrothermal systems in prebiotic chemistry could be much more complex that thought.

Keywords: Hydrothermal vents, ionizing radiation, thermal energy, acetic acid, formic acid, prebiotic chemistry.

\section{RESUMEN}

Los sistemas hidrotermales se han propuesto como entornos favorables en la Tierra primitiva, en los cuales podrian haber ocurrido procesos de evolución química. La presencia de minerales y un flujo continuo de energía se destacan entre las condiciones más notables en dichos entornos. En esta investigación se estudió la descomposición de dos ácidos orgánicos. La radiación ionizante y el calor fueron las fuentes de energía seleccionadas para las pruebas de descomposición, ya que ambas están presentes de forma natural en los sistemas hidrotermales y, probablemente, estuvieron presentes en la Tierra primitiva. La radiación podría provenir de elementos inestables en minerales y el calor es la fuente de energía más abundante en los sistemas hidrotermales. Dado que los minerales juegan un papel clave en los experimentos de química prebiótica y son un componente esencial en ambientes hidrotermales, se probó el papel del olivino en la descomposición de los ácidos. Los resultados indican que ambos ácidos orgánicos se descomponen altamente cuando se irradian o se calientan. La radiación es más eficaz que el calentamiento para descomponer los ácidos carboxílicos y formar otros. Curiosamente, la presencia de olivino afecta la descomposición tanto en muestras calentadas como irradiadas, ya que tanto la velocidad de descomposición como la cantidad y tipo de productos varian en comparación con los experimentos sin el mineral. En todas las muestras se siguió la formación de otros ácidos carboxílicos. Se detectaron el ácido succínico, tricarballílico, cítrico y carboxisuccínico en experimentos de radiolisis de ácido acético. La radiolisis del ácido fórmico produjo oxálico y tartrónico. El calentamiento de las soluciones de ácido acético formó los ácidos succínicos, tricarballílico, cítrico y carboxisuccínico. Sin embargo, el calentamiento del ácido fórmico solo generó ácido oxálico. La presencia de olivino afectó la cantidad y el tipo de ácidos carboxílicos formados por la radiación y experimentos sobre calentamiento. Los sistemas hidrotermales naturales son entornos complejos y en ellos están presentes muchas variables. Nuestros resultados refuerzan la idea de que es necesaria una combinación de variables para una mejor simulación de estos entornos en experimentos de química prebiótica. Todas las variables podrian haber afectado las reacciones químicas prebióticas; $y$, por lo tanto, el papel de los sistemas hidrotermales en la química prebiótica podría ser mucho más complejo de lo que se pensaba.

Palabras clave: Sistemas hidrotermales, radiación ionizante, energía térmica, ácido acético, ácido fórmico, química prebiótica. 


\section{Introduction}

The emergence of life on Earth is thought to have been preceded by a period of interactions among the ocean, the lithosphere and the atmosphere; as a result of such interactions organic molecules originated from inorganic precursors, which is a set of processes collectively labeled as "chemical evolution" (Lemmon, 1970; Malaterre, 2015). These processes led to the generation of the organic basis of life. It has been proposed that a heterogeneous and inorganic system should have guided the increase in complexity of those molecules.

The chemical reactions that gave way to complex organic matter could have occurred on different environments; among them on hydrothermal systems. A hydrothermal system, either submarine or subaerial, is an environment in which hot fluids circulate through permeable or fractured rocks and generates in a broad variety of geological settings (Pirajno, 2009).

Because of their geochemical properties, hydrothermal vents systems (HVS) were proposed as environments where prebiotic chemical evolution could have occurred (Corliss et al., 1980, 1981; Baross and Hoffman, 1985; Staudigel, 2003; Colín-García et al., 2016, 2018; Westall et al., 2018). Among the most conspicuous variables present on those environments, energy sources, mineralogical diversity, and physicochemical gradients $(\mathrm{pH}$, temperature, Eh) involved in abiotic organic synthesis, were probably also relevant in a prebiotic scenario.

The main source of energy in hydrothermal systems is noticeably thermal (Miller and Urey, 1959; Baross and Hoffman, 1985; Santosh et al., 2017); geological processes imply the generation of a variety of temperature gradients through the water column and host rocks (Colín-García et al., 2016, 2018). These temperature gradients support the hypothesis that prebiotic chemistry could have occurred in hydrothermal systems (Corliss et al., 1981; Colín-García et al., 2016, 2018). Besides thermal energy, radiation -in particular, ionizing energy- holds up in HVS. This energy was much more abundant on the early Earth $\left(3 \times 10^{18} \mathrm{~J} /\right.$ year at one-kilometer depth) about 4,000 Ma (Garzón and Garzón, 2001). Ionizing radiation could have come from the decay of radioactive elements that occur naturally in many minerals, and also from radioactive ions dissolved in water, such as ${ }^{40} \mathrm{~K}$ (Draganić et al., 1991) and from cosmic radiation (Draganić and Draganić 1978).

The possible role of solid surfaces (minerals and rocks) in promoting or harboring reactions that preceded life was crucial (Bernal, 1951; Rimola et al., 2019). Minerals could have protected organics against the decomposition induced by energy present on the environment; they could also concentrate or accumulate organics and catalyze polymerization reactions, by inducing a molecular rearrangement (Hashizume, 2015). The first minerals used as models to carry out prebiotic simulation experiments were clays (Bernal, 1951), and they remain the most common minerals used in experiments related to the simulation of primitive environments (Bernal, 1951; Lahav and White, 1980; Rao et al., 1980; Negrón-Mendoza et al., 2004a; Hashizume, 2012).These minerals are widely diversified on the Earth's surface and have a strong affinity for organic matter (Negrón-Mendoza et al., 2004b; Ferris 2005). Other silicates, such as quartz (i.e. Bonner, et al. 1975; Zaia et al., 2018) or feldspar (for example, Smith, 1998; Parsons et al.,1998; Rimola et al., 2007), have been deemed important in prebiotic chemistry studies, since silicates, as a group, constitute over $90 \%$ of the mantle and crustal rocks (Dana et al., 1979).

Olivine is a silicate widely distributed on Earth. The magnesium end member of the olivine series (forsterite, $\mathrm{MgSiO}_{4}$ ) is the main constituent of Earth's mantle (Smyth and Hazen, 1973; Deer et al., 1982). One of the most important reservoirs of olivine is oceanic crust, which is essentially composed of basalt, and olivine is the most important component of this rock (up to $60 \%$ ). Besides, it is likely that olivine rich-ultramafic rocks hosted hydrothermal systems in early Earth (Russell et al., 2010).

Carboxylic acids are molecules that could have been easily synthesized at the Earth's primitive surface (Kitadai and Maruyama, 2018), and they are subject of studies in diverse prebiotic exper- 
iments (Negrón-Mendoza and Ponnamperuma, 1976; Cody et al., 2001; Guzman and Martin, 2009). The simplest molecules belonging to this group are acetic and formic acid. Formic acid $(\mathrm{HCOOH})$ is the simplest organic acid; in living organisms, it participates in different cellular metabolic pathways to obtain energy through fermentation (McKee and McKee, 2003). The second simplest carboxylic acid is acetic $\left(\mathrm{CH}_{3} \mathrm{COOH}\right)$, an important precursor in the cellular respiration cycle. It has been widely studied in prebiotic simulations using ionizing radiation as energy source (Calvin, 1956; Negrón-Mendoza, 1980). Given the importance of carboxylic acids in biological processes, authors such as Ferris (1992) and Simoneit (2004), have studied the behavior of carboxylic acids under hydrothermal conditions.

The chemical reactions occurring at HVS are complex now and it is expected that prebiotic reactions on early Earth were too. In order to contribute to the understanding of the role of those systems on prebiotic chemistry, simple experiments have been designed. In this research the decomposition of two carboxylic acids (formic and acetic acids) exposed to conditions resembling those present on HVS (energy sources and mineral) was studied. Firstly, the decomposition of organic acids exposed to different energy sources (thermal and ionizing energy) was evaluated; later, the effect of a mineral (olivine) was tested in order to determine how it affects the decomposition and the formation of other carboxylic acids; and, finally, the relevance in prebiotic chemistry is discussed.

\section{Materials and methods}

Glassware was cleaned out with a hot mixture of nitric and sulphuric acids, according to radiation chemistry procedures (O'Donnell and Sangster, 1970). Additionally, the water used for all the experiments was triple distilled, since impurities in the solution strongly influence the radiolysis products.

\subsection{MINERAL GLEANING AND GHARAGTERIZATION}

Olivine (a mixture of different grain sizes) was cleaned to remove any organic residue, first with an acidic $\left(\mathrm{HNO}_{3}, 3 \%\right)$, and then with a basic solution $(\mathrm{KOH}, 3 \%)$, finally it was rinsed with triple distilled water and dried at room temperature. After that, olivine was characterized by scanning electron microscopy in a JEOL JXA-8900R by EDS (X-ray scatter spectrometry) at $20 \mathrm{kV}$ for qualitative characterization, and WDS (X-ray wavelength dispersion spectrometry), at the Laboratory of Petrology (LUP) of the Geophysics Institute, UNAM. For WDS analysis thin sheets of the mineral were prepared. Selected points were analyzed to quantify the elemental content.

\subsection{SOLUTIONS}

Solutions of organic acids were prepared in triple distilled water: a solution of acetic acid (Baker, purity $\geq 97.7 \%$ ) at $0.01 \mathrm{~mol} \cdot \mathrm{L}^{-1}$, and one of formic acid (Aldrich, purity $\geq 95 \%$ ) at $0.3 \mathrm{~mol} \cdot \mathrm{L}^{-1}$. These concentrations were selected based on the detection limit of the analytical techniques used.

\subsection{RADIOLYSIS EXPERIMENTS}

Two different experiments were carried out. The first contained only the organic molecule in solution, the other the organic acid in solution and olivine fragments.

Solution samples. $5 \mathrm{~mL}$ of each organic acid solution (acetic or formic) were placed in glass ampoules. All samples were degassed by bubbling argon for 15 minutes; after that, samples were irradiated. Irradiation was done in a gamma ray source, originated from ${ }^{60} \mathrm{Co}$ (Gamma-beam 651-PT, at the Instituto de Ciencias Nucleares, UNAM). The dose was estimated by a ferrous sulphate-copper sulphate dosimeter (the Fricke Dosimeter). The samples were exposed to different doses (until $185 \mathrm{kGy}$ ).

Mineral containing samples. Heterogeneous samples, those containing olivine, were prepared by mixing in glass ampoules $1 \mathrm{~g}$ of the 
mineral with $5 \mathrm{~mL}$ of the organic acid solution. Samples were also bubbled with argon for 15 minutes and then sealed. The $\mathrm{pH}$ of samples was measured before and after irradiation.

\subsection{THERMOLYSIS EXPERIMENTS}

A heating system was used, this consisted of a glass recirculation appliance, containing toluene (b. p. $95^{\circ} \mathrm{C}$ ) as the heating fluid. After 35 minutes of heating (at a rate of $2^{\circ} \mathrm{C} \cdot \mathrm{min}^{-1}$ ) the final temperature was reached, then it was hold. Samples were placed just when this temperature was reached.

Solution samples. $3 \mathrm{~mL}$ of each solution (acetic $0.01 \mathrm{~mol} \cdot \mathrm{L}^{-1}$ or formic $0.3 \mathrm{~mol} \cdot \mathrm{L}^{-1}$ ) were put in glass tubes, samples were bubbled with argon before heating and ampoules were sealed. Samples were heated at $95{ }^{\circ} \mathrm{C}$ for different time intervals (24, 48, 96, and $120 \mathrm{~h}$ ).

Mineral containing samples. The samples were prepared by adding $1 \mathrm{~g}$ of mineral into $5 \mathrm{~mL}$ of solution. Samples were degassed with argon (bubbling 15 minutes); and then they were heated in the same way as solution samples.

\subsection{ANALYSIS OF SAMPLES}

In order to follow up the decomposition of the molecule, samples were analyzed by liquid chromatography on an HPLC system (515-pump from Waters ${ }^{\circledR}$ Corp.), coupled with a Single Quadrupole Mass Detection system (SQ-2 manufactured by Waters Corp.), and an electro spray ionization instrument in negative mode (ESI-). The specific conditions of analysis for both acids are described in next paragraphs.

Acetic acid. The working conditions were adjusted for capillary of $1.73 \mathrm{kV}$, cone of $21 \mathrm{~V}$, at a temperature of $350{ }^{\circ} \mathrm{C}$, a desolvation gas flow of $650 \mathrm{~L} / \mathrm{h}$, a Symmetry C18 column $(4.6 \mathrm{x}$ $75 \mathrm{~mm}, 3.5 \mu \mathrm{m}$ spherical particle size, by Waters ${ }^{\circledR}$ Corp.) under an isocratic elution of a mobile phase $(100 \%$ HPLC/MS water at $\mathrm{pH}=7)$, and at flow of $0.3 \mathrm{~mL} / \mathrm{min}$. A sample volume $(20 \mu \mathrm{L})$ was injected using a loop.
Formic acid. The working conditions were adjusted for capillary of $1.58 \mathrm{kV}$, cone of $19 \mathrm{~V}$, at a temperature of $350{ }^{\circ} \mathrm{C}$, a desolvation gas flow of $650 \mathrm{~L} / \mathrm{h}$, a Symmetry C18 column (4.6 x 75mm, 3.5 $\mu \mathrm{m}$ spherical particle size, by Waters ${ }^{\circledR}$ Corp.) was used under an isocratic elution of a mobile phase (50\% HPLC-MS methanol and $50 \%$ HPLC-MS water at $\mathrm{pH}=7)$, and at flow of $0.3 \mathrm{~mL} / \mathrm{min}$. A sample volume $(20 \mu \mathrm{L})$ was injected using a loop. The products of radiolysis were detected by HPLC-MS following the molecular ion of produced species.

\section{Results}

\subsection{OLIVINE GHARACTERIZATION}

According to the results, olivine appertains to the end member forsterite, since magnesium is in greater proportion $(49 \%)$ than the iron $(10.33 \%)$ (Deer et al., 1982). Analyses also indicate that olivine contains inclusions of chromite (Figure 1), which is very common on the mineral (Kamenetsky et al., 2002; Spandler et al., 2007). Other elements were found in the sample, such as nickel $(0.43 \%)$ and manganese $(0.14 \%)$.
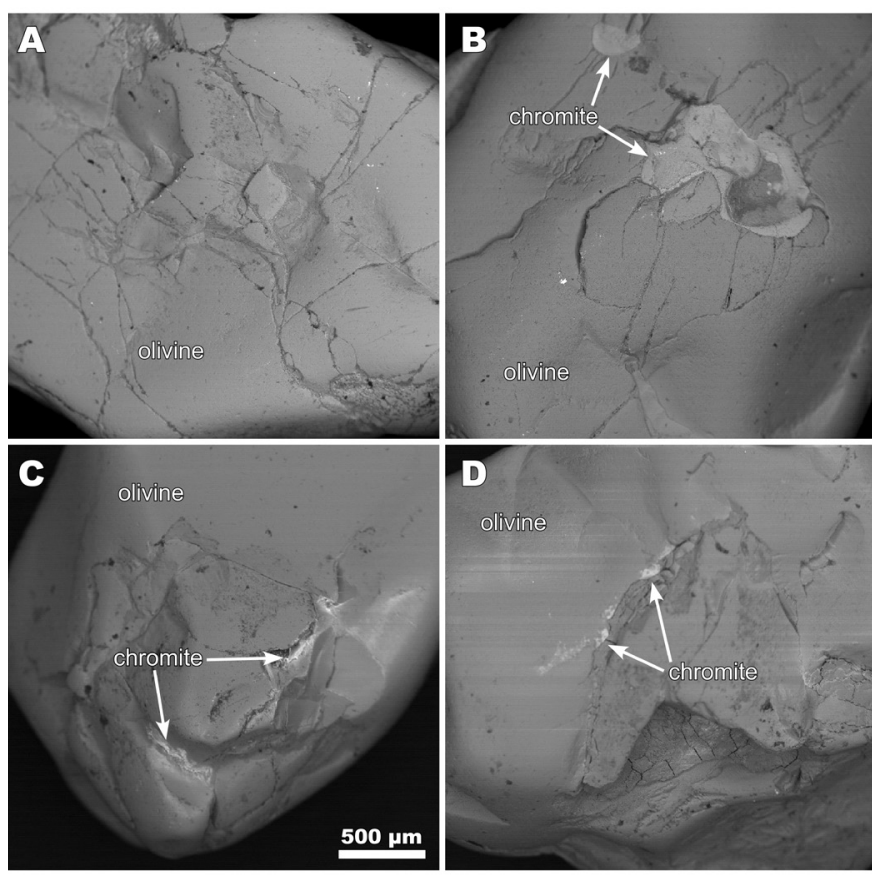

Figure 1 Photomicrographs of olivine samples, chromite inclusions are shown. 


\subsection{RADIOLYSIS}

In general, when the two acids were exposed to ionizing radiation there is decomposition as the dose increases. Nonetheless, the decomposition is different for both systems.

Acetic acid radiolysis. In the case of acetic acid, as dose increases decomposition of the molecule also does. At $185 \mathrm{kGy}$ (the higher dose) the acetic solution shows the maximum decomposition, and only $0.85 \%$ of the acid was recovered. In the case of the system including olivine the amount recovered is higher at the same dose, and $10 \%$ is recovered (Figure 2).

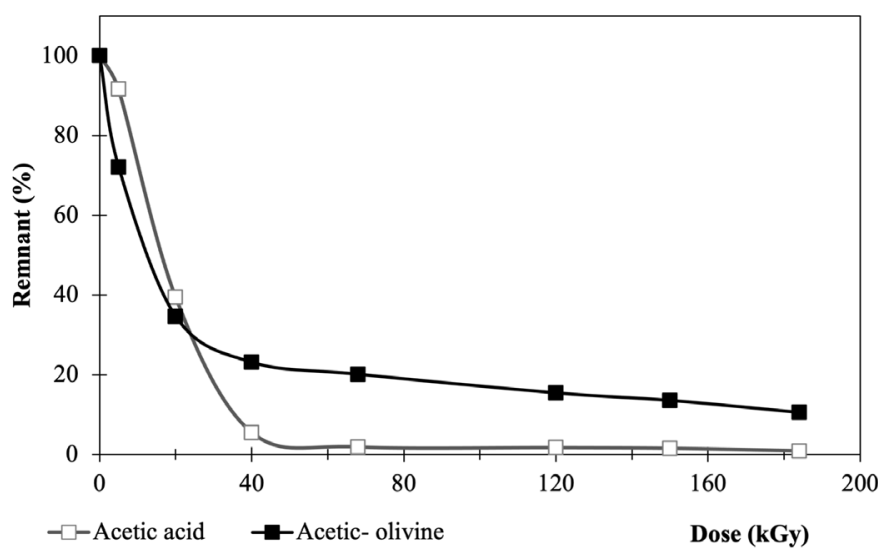

Figure 2 Acetic acid remnant in homogeneous ( $\square$ Acetic acid solution) and heterogeneous - Acetic-olivine) samples exposed to ionizing radiation (up to $185 \mathrm{kGy}$ ). As dose increases decomposition of the molecule occurs, decomposition is higher in homogeneous samples, without the mineral.

The formation of some radiolytic products from acetic acid irradiation was also confirmed by HPLC-MS (Figure 3). The main product from radiolysis of acetic acid is acetaldehyde, as previously reported (Negrón-Mendoza and Navarro-González, 1990) but it was not quantified here, since we were interested in detecting the formation of other carboxylic acids. The mineral influences the decomposition rate of acetic acid, and the formation of products. Succinic, tricarballylic, and citric acid were formed from acetic acid solutions irradiation (Tables 1 and 2). There is a succession of products, firstly succinic acid is formed at low concentration and low radiation doses; then starts the formation of tricarballylic acid; and, finally citric acid is formed at higher concentrations (on the order of $10^{-4} \mathrm{~mol} \cdot \mathrm{L}^{-1}$ ).

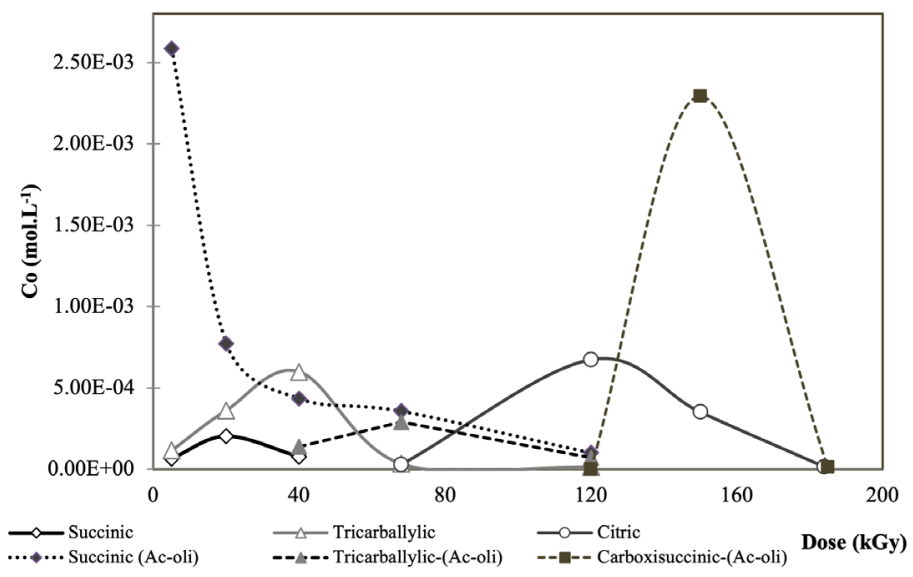

Figure 3 Dynamic formation of carboxylic acids resulted from the radiolysis of acetic acid solutions as a function of dose. The formation is shown in mol. $\mathrm{L}^{-1}$. Data show the behavior of samples irradiated in solution (solid lines) or with olivine (dashed lines). In the first case, the formation of succinic, tricarballylic and citric acid was confirmed. While, in the samples irradiated with the mineral, succinic, tricarballylic and carboxisuccinic acid were formed.

Table 1. Carboxylic acids formed by the radiolysis of acetic acid solutions. The concentration is shown in $\left(\mathrm{mol}^{-\mathrm{L}^{-1}}\right)$.

\begin{tabular}{|c|c|c|c|}
\hline \multirow{2}{*}{$\begin{array}{c}\text { Dose } \\
(\mathrm{kGy})\end{array}$} & \multicolumn{3}{|c|}{$\begin{array}{c}\text { Carboxylic acid } \\
\text { Co }\left(\mathrm{mol} \cdot \mathrm{L}^{-1}\right)\end{array}$} \\
\cline { 2 - 4 } & Succinic & Tricarballilic & Citric \\
\hline 0 & -- & -- & -- \\
\hline 5 & $6.618 \times 10^{-5}$ & $1.154 \times 10^{-4}$ & -- \\
\hline 20 & $2.045 \times 10^{-4}$ & $3.619 \times 10^{-4}$ & -- \\
\hline 40 & $7.667 \times 10^{-5}$ & $5.989 \times 10^{-4}$ & -- \\
\hline 68 & -- & $3.432 \times 10^{-5}$ & $3.011 \times 10^{-5}$ \\
\hline 120 & -- & $1.558 \times 10^{-5}$ & $6.741 \times 10^{-4}$ \\
\hline 150 & -- & -- & $3.519 \times 10^{-4}$ \\
185 & -- & -- & $1.619 \times 10^{-5}$ \\
\hline
\end{tabular}

Table 2. Carboxylic acids formed by the radiolysis of acetic acid with olivine. The concentration is shown in $\left(\mathrm{mol}^{-\mathrm{L}^{-1}}\right)$.

\begin{tabular}{|c|c|c|c|}
\hline \multirow{2}{*}{$\begin{array}{c}\text { Dose } \\
(\mathrm{kGy})\end{array}$} & \multicolumn{3}{|c|}{$\begin{array}{c}\text { Carboxylic acid } \\
\text { Co }\left(\text { mol: } \mathrm{L}^{-1}\right)\end{array}$} \\
\cline { 2 - 4 } & Succinic & Tricarballilic & Carboxisuccinic \\
\hline 0 & -- & -- & -- \\
\hline 5 & $2.59 \times 10^{-3}$ & -- & -- \\
\hline 20 & $7.73 \times 10^{-4}$ & -- & -- \\
\hline 40 & $4.35 \times 10^{-4}$ & $1.38 \times 10^{-4}$ & -- \\
\hline 68 & $3.57 \times 10^{-4}$ & $2.91 \times 10^{-4}$ & -- \\
\hline 120 & $1.01 \times 10^{-4}$ & $7.04 \times 10^{-4}$ & -- \\
\hline 150 & -- & -- & $2.29 \times 10^{-3}$ \\
\hline 185 & -- & -- & $1.12 \times 10^{-5}$ \\
\hline
\end{tabular}

Note: The formation of carboxisuccinic acid occurs, and citric acid is not formed. 
Formic acid radiolysis. As dose increases, decomposition of the molecule arises; the decomposition rate suggests that this acid is highly sensitive to radiation. There is a difference among the samples irradiated in solution and those containing the mineral. The presence of the mineral, in this case, accelerates decomposition (Figure 4); and at $150 \mathrm{kGy}$ there is no more formic acid in solution. At the same dose, $8 \%$ of the carboxylic acid is recovered in the irradiated mineral free samples.

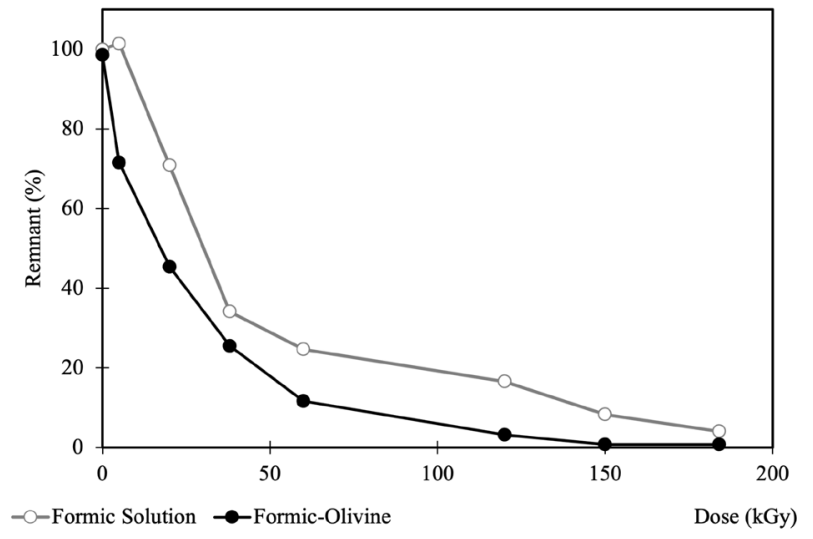

Figure 4 Formic acid recovery in homogeneous ( $\circ$ Formic Solution) and heterogeneous (• Formic-olivine) samples exposed to ionizing radiation (up to $185 \mathrm{kGy}$ ).

In the case of formic acid irradiation, only two carboxylic acids were detected and quantified: oxalic and tartronic (Figure 5). The production of those carboxylic acids was higher in irradiated solutions without the mineral (Tables 3 and 4).

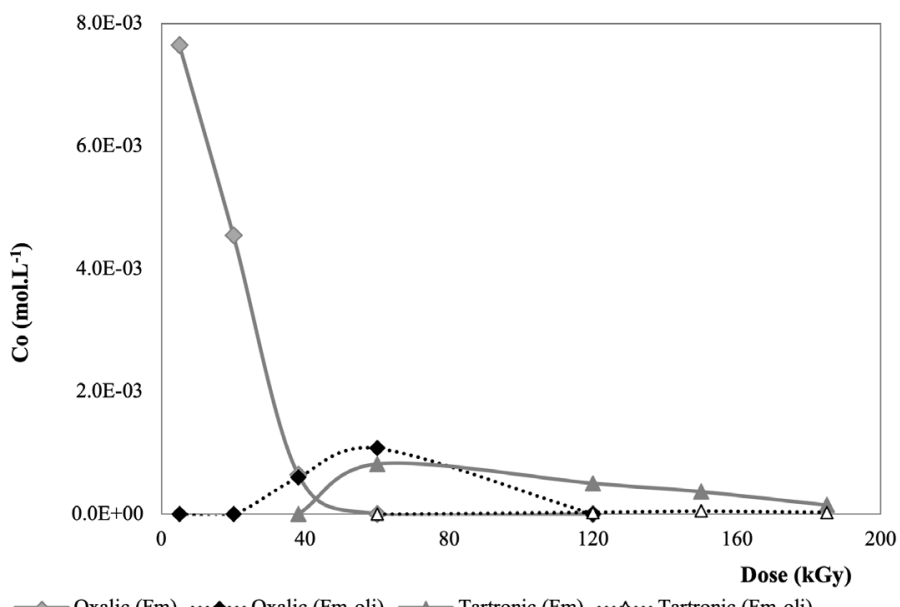

$\sim$ Oxalic $(\mathrm{Fm}) \cdots \cdots$ Oxalic (Fm-oli) $\longrightarrow$ Tartronic $(\mathrm{Fm}) \cdots \cdots$ Tartronic $($ Fm-oli)

Figure 5 Carboxylic acids formed by the radiolysis of formic acid. Oxalic and tartronic acid are formed both in experiments with olivine [dashed lines: Oxalic (Fm-oli)]; Tartronic (Fm-oli) and without the mineral [continuous lines: Oxalic-(Fm), Tartronic (Fm)].
Table 3. Carboxylic acids formed by the radiolysis of formic acid solutions. The concentration is shown in $\left(\mathrm{mol}^{-\mathrm{L}^{-1}}\right)$.

\begin{tabular}{|c|c|c|}
\hline \multirow{2}{*}{$\begin{array}{c}\text { Dose } \\
(\mathbf{k G y})\end{array}$} & \multicolumn{2}{|c|}{ Carboxylic acid formed } \\
\cline { 2 - 3 } & Oxalic & Tartronic \\
\hline 0 & - & - \\
\hline 5 & $7.649 \times 10^{-3}$ & $1.154 \times 10^{-4}$ \\
\hline 20 & $4.548 \times 10^{-3}$ & $3.619 \times 10^{-4}$ \\
\hline 38 & $6.493 \times 10^{-4}$ & $5.989 \times 10^{-4}$ \\
60 & - & $3.432 \times 10^{-5}$ \\
\hline 120 & - & $1.558 \times 10^{-5}$ \\
150 & - & - \\
\hline 185 & - & - \\
\hline
\end{tabular}

Table 4. Carboxylic acids formed by the radiolysis of formic acid

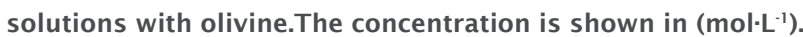

\begin{tabular}{|c|c|c|}
\hline \multirow{2}{*}{$\begin{array}{c}\text { Dose } \\
(\mathbf{k G y})\end{array}$} & \multicolumn{2}{|c|}{ Carboxylic acid formed } \\
\cline { 2 - 3 } & Oxalic & Tartronic \\
\hline 0 & - & - \\
\hline 5 & - & - \\
\hline 20 & - & - \\
\hline 38 & $5.973 \times 10^{-4}$ & - \\
\hline 60 & $1.076 \times 10^{-3}$ & - \\
\hline 120 & - & $2.858 \times 10^{-5}$ \\
\hline 150 & - & $5.286 \times 10^{-5}$ \\
\hline 185 & - & $2.799 \times 10^{-5}$ \\
\hline
\end{tabular}

$\boldsymbol{G}_{0^{*}}$ values. The $\mathrm{G}$ value is the number of molecules destroyed by $100 \mathrm{eV}$ (Spinks and Wood 1990). We calculated the $G_{0}$ value for all systems, values are shown in Table 5. The values indicate that in solution acetic acid $\left(\mathrm{G}_{0}=3.28\right)$ is more labile than formic acid $\left(\mathrm{G}_{0}=1.45\right)$. It is also noticeable that the mineral affects the radiolysis of both organic acids; it reduces slightly the decomposition in the case of acetic acid with olivine $\left(\mathrm{G}_{0}=3.02\right)$; and it strongly increases decomposition of formic acid $\left(G_{0}=4.13\right)$.

Table 5. Calculated $G_{0}$ values for the studied systems.

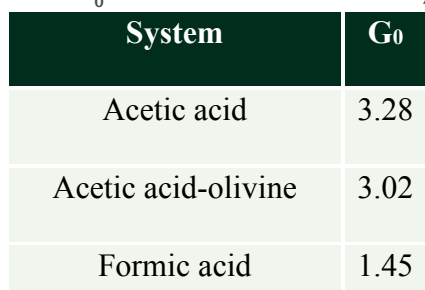

Formic acid-olivine $\quad 4.13$ 
$\boldsymbol{p H}$ variation. Differences on $\mathrm{pH}$ values bring us some clues about the chemical changes in the irradiated samples. In Figure 6 the $\mathrm{pH}$ values are shown for all studied systems. All olivine bearing samples show a $\mathrm{pH}$ increase. After irradiation, some samples show small $\mathrm{pH}$ variations. In the case of acetic acid solutions, there is a decrement in $\mathrm{pH}$ after irradiation. For formic acid, a slightly increment is noticeable.
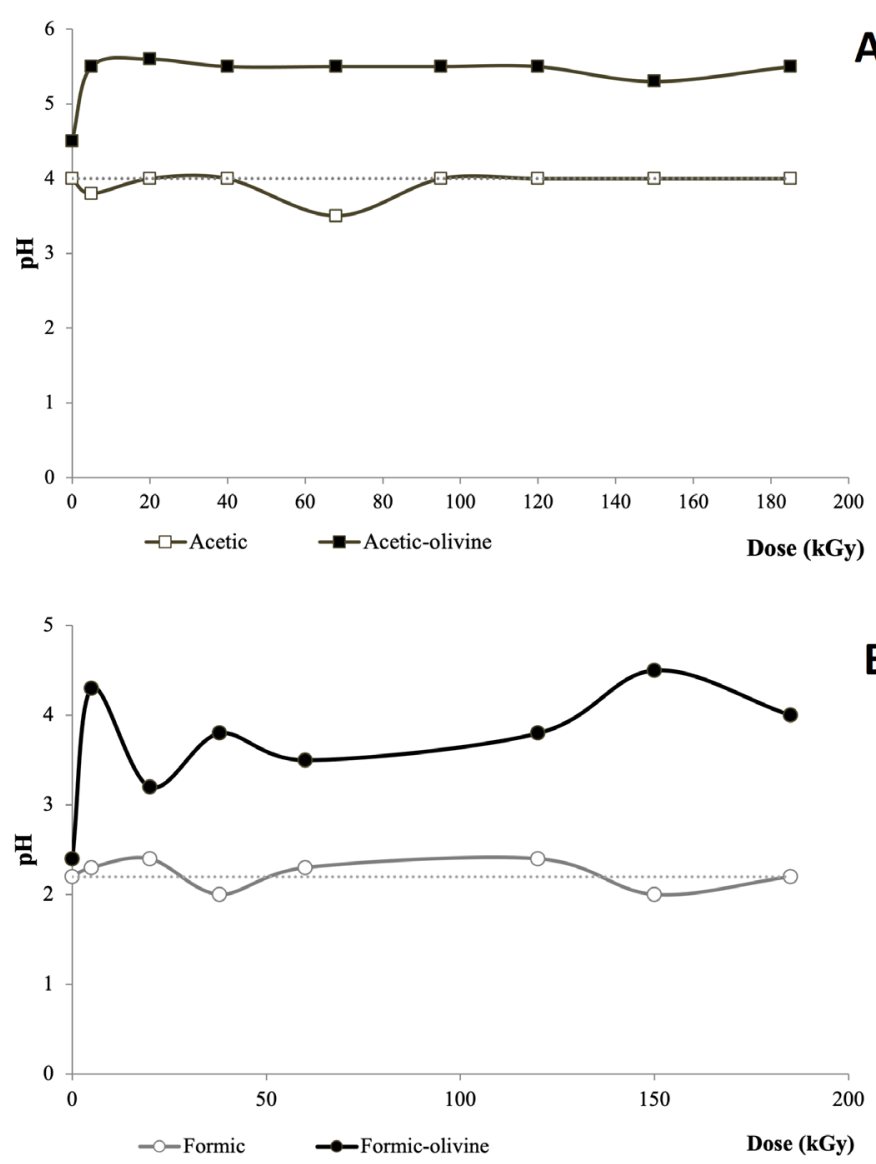

Figure 6 pH variation in irradiated samples; (A) acetic acid $\left(0.01 \mathrm{~mol} \cdot \mathrm{L}^{-1}\right)$ and $(B)$ formic acid $\left(0.3 \mathrm{~mol} \cdot \mathrm{L}^{-1}\right)$. The dashed line is the reference value for a solution of non-irradiated carboxylic acid.

\subsection{THERMOLYSIS}

Acetic acid thermolysis. The heating of samples at $95^{\circ} \mathrm{C}$ produced the decomposition of acetic acid, in both free solutions, and in presence of the mineral (Figure 7). After $120 \mathrm{~h}$ of heating, $37 \%$ of the acid is recovered in samples that contained only acetic acid; while the presence of olivine produces a minor decomposition; and at the same heating time, $46 \%$ of the acid was recovered.

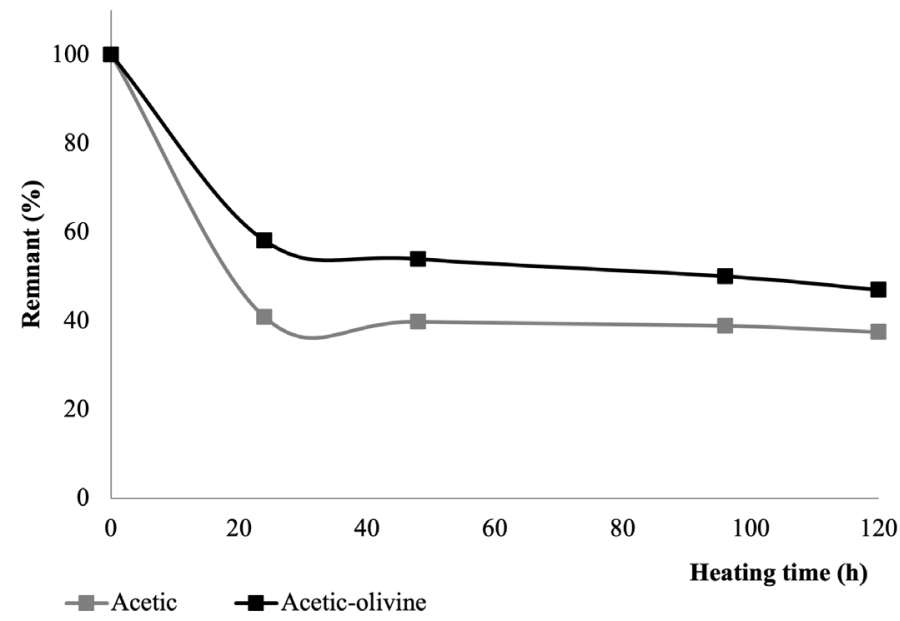

Figure 7 Decomposition of acetic acid $\left(\right.$ at $95^{\circ} \mathrm{C}$ ) as a function of heating time. The thermolysis with and without olivine is shown.

The thermolysis of acetic acid also generates other carboxylic acids (Figure 8). In the case of solutions of acetic acids, succinic, tricarballylic, carboxisuccinic and citric acids were formed (Table 6). In the case of samples containing olivine, succinic acid was not formed (Table 7).

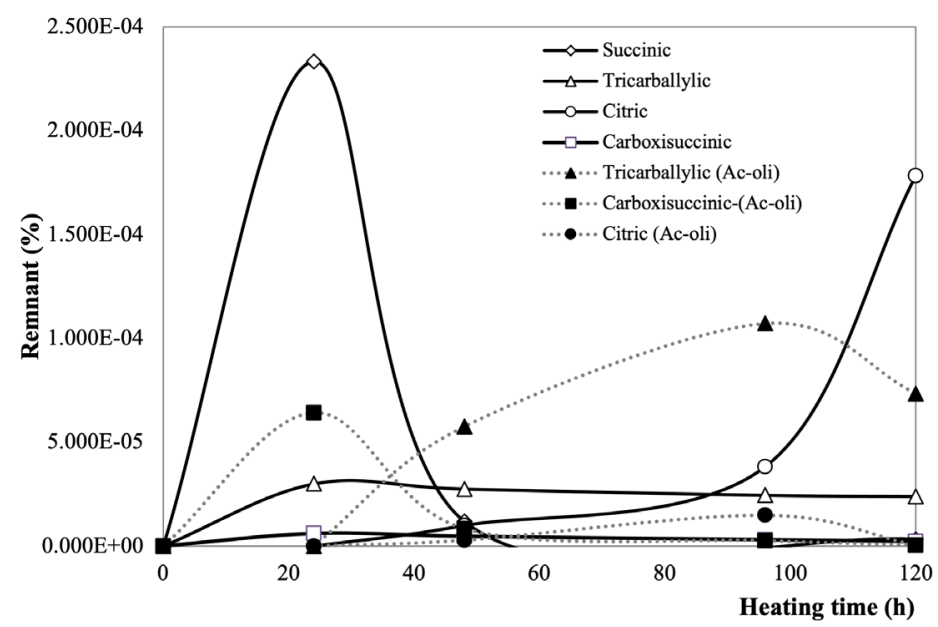

Figure 8 Carboxylic acids formed by acetic acid thermolysis: succinic, tricarballylic, citric and carboxisuccinic acids were detected. Succinic acid is formed only in thermolysis experiments without olivine. Continuous lines show products formed by the thermolysis of acetic acids solutions. Dashed lines show the products formed in experiments with the mineral. 
Table 6. Carboxylic acids formed by the thermolysis of acetic acid solutions.

\begin{tabular}{c|c|c|c|c|}
\hline \multirow{2}{*}{$\begin{array}{c}\text { Time } \\
(\mathrm{h})\end{array}$} & \multicolumn{4}{|c|}{$\begin{array}{c}\text { Carboxylic acid } \\
\text { Co }\left(\mathrm{molL}^{-1}\right)\end{array}$} \\
\cline { 2 - 5 } & Succinic & Tricarballilic & Citric & Carboxisuccinic \\
\hline 0 & & & & $6.178 \times 10^{-6}$ \\
\hline 24 & $2.333 \times 10^{-4}$ & $2.998 \times 10^{-5}$ & & $4.790 \times 10^{-6}$ \\
\hline 48 & $1.182 \times 10^{-4}$ & $2.752 \times 10^{-5}$ & $9.941 \times 10^{-6}$ & $3.084 \times 10^{-6}$ \\
96 & & $2.448 \times 10^{-5}$ & $3.825 \times 10^{-5}$ & $3.247 \times 10^{-6}$ \\
\hline 120 & $3.28810^{-6}$ & $2.391 \times 10^{-5}$ & $1.783 \times 10^{-4}$ & $2.24 \times 1$ \\
\hline
\end{tabular}

Table 7. Carboxylic acids formed by the thermolysis of acetic acid solutions in contact with olivine.

\begin{tabular}{|c|c|c|c|}
\hline \multirow{2}{*}{$\begin{array}{c}\text { Time } \\
(\mathrm{h})\end{array}$} & \multicolumn{3}{|c|}{$\begin{array}{c}\text { Carboxylic acid } \\
\text { Co }\left(\mathrm{mol} \mathrm{L}^{-1}\right)\end{array}$} \\
\hline 0 & Tricarballilic & Citric & Carboxisuccinic \\
\hline 0 & & & \\
\hline 24 & & & $6.426 \times 10^{-5}$ \\
\hline 48 & $5.750 \times 10^{-5}$ & $2.76810^{-6}$ & $8.307 \times 10^{-6}$ \\
96 & $1.072 \times 10^{-4}$ & $1.485 \times 10^{-5}$ & $2.593 \times 10^{-6}$ \\
\hline 120 & $7.349 \times 10^{-5}$ & $2.763 \times 10^{-7}$ & $3.121 \times 10^{-7}$ \\
\hline
\end{tabular}

Formic acid thermolysis. In the case of formic acid thermolysis, decomposition was observed as a function of heating time (Figure 9). The system without olivine shows the higher decomposition, at $120 \mathrm{~h}$ of heating only $5 \%$ remains. In this case, only oxalic acid was formed (Table 8). Given that formaldehyde is reported as a product in the decomposition of formic acid by thermolysis (Nelson and Engelder, 1926) an internal standard test was injected to check the presence of this molecule. The results indicate that formaldehyde is produced by heating, but it was not possible to quantify the formation of this molecule (results are not shown).

$\boldsymbol{p H}$ variation. The changes in the $\mathrm{pH}$ of the heated samples were recorded (Figure 10). Olivine generates an increment of $\mathrm{pH}$ in all samples. Like in radiolysis experiments, the higher change occurred in the formic-olivine system that increased from 2.2 to 4 .

Table 8. Production of oxalic acid by the thermolysis of formic acid solutions.

\begin{tabular}{|c|c|c|}
\hline \multirow{2}{*}{$\begin{array}{c}\text { Heating } \\
\text { time(h) }\end{array}$} & \multicolumn{2}{|c|}{ Oxalic Co $\left(\mathrm{mol}^{-\mathbf{1}}\right)$} \\
\hline 0 & In solution & With olivine \\
\hline 24 & $2.824 \times 10^{-3}$ & $6.232 \times 10^{-4}$ \\
\hline 48 & $9.136 \times 10^{-3}$ & $9.158 \times 10^{-4}$ \\
\hline 96 & $6.919 \times 10^{-3}$ & $1.419 \times 10^{-3}$ \\
\hline 120 & $5.462 \times 10^{-3}$ & $4.147 \times 10^{-3}$ \\
\hline
\end{tabular}

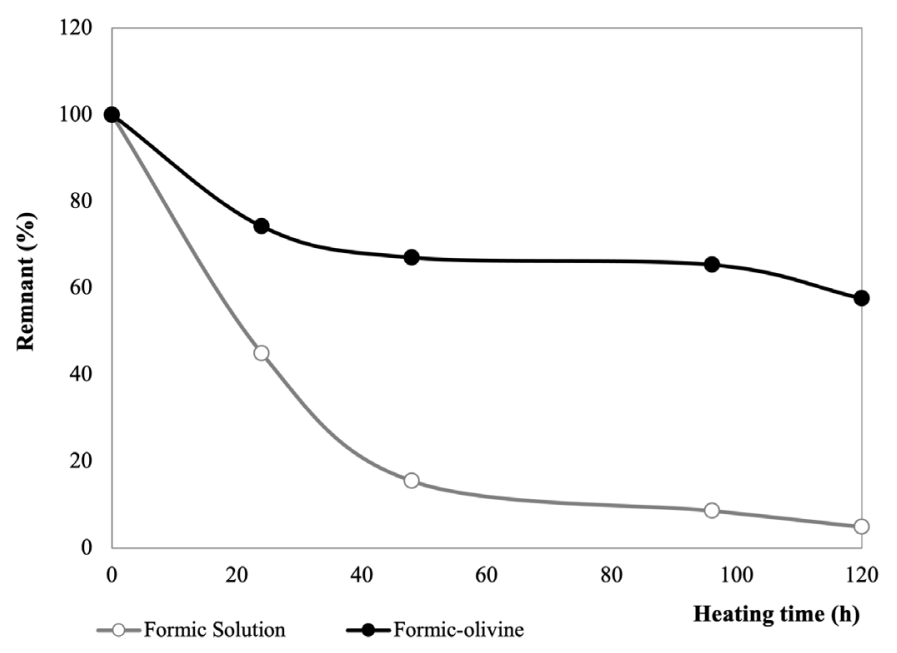

Figure 9 Remnant of formic acid $\left(95^{\circ} \mathrm{C}\right)$ as a function of heating time. Decomposition of formic acid in homogeneous ( $\circ$ Formic solution) is higher compared to heterogeneous samples (• Formic-olivine).
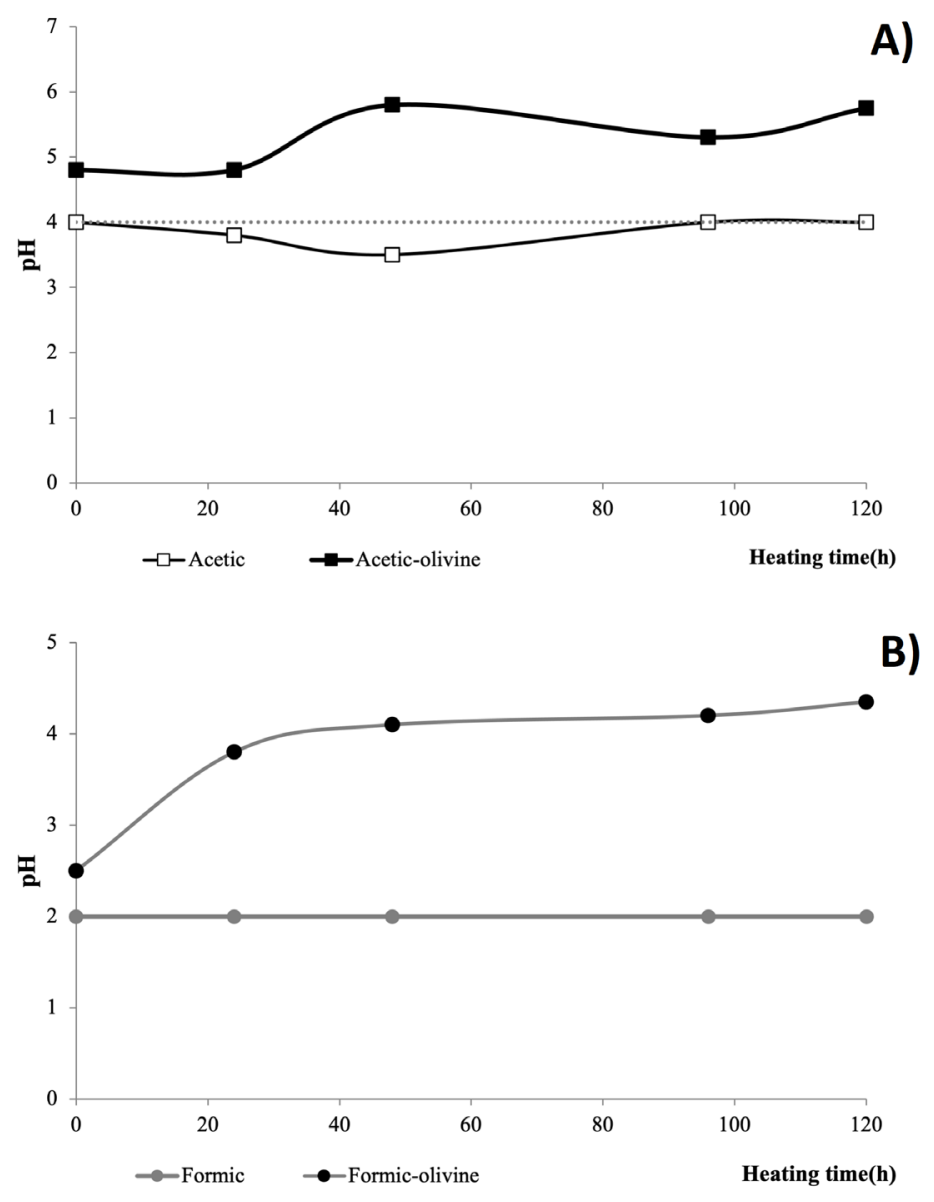

Figure $10 \mathrm{pH}$ variation in thermolysis experiments. (A) acetic acid $\left(0.01 \mathrm{~mol} \cdot \mathrm{L}^{-1}\right)$ and $(B)$ formic acid $\left(0.3 \mathrm{~mol} \cdot \mathrm{L}^{-1}\right)$. The dashed line is the reference value for a solution of non irradiated carboxylic acid. 


\section{Discussion}

\subsection{RADIOLYSIS}

Acetic acid. The interaction of radiation with acetic acid induces a highly decomposition of the molecule and it has been well studied (Burr, 1957; Neta, et al., 1969; Lukáč et al., 1972; Josimović and Draganić, 1973; Josimović et al., 1976). Decomposition of this acid leads mainly to the formation of other carboxylic acids, among them: succinic, malonic, tricarballylic, citric, isocitric, beta hydroxyl-betamethylglutaric, and aconitic (Neta et al., 1969; Josimović and Draganić, 1973; Navarro-González et al., 1990; Criquet and Leitner, 2011). In this research succinic, malonic, tricarballylic, and citric acid were identified at low concentrations (up to $10^{-4} \mathrm{~mol} \cdot \mathrm{L}$ ). All these organic molecules are involved in one of the most important metabolic pathways for living beings, the Krebs cycle. Therefore they are relevant compounds for understanding the evolution of organic molecules on early Earth (Negrón-Mendoza and Ponnamperuma, 1976; Negrón, 1980; Gordeev et al., 2007).

The formation of these molecules can be explained, in principle, by the formation of reactive species from the radiolysis of water. On solution, the most abundant component is water, and then radiation interacts mainly with those molecules. The species formed by the radiolysis of water (Reaction 1) play a decisive role in the decomposition of carboxylic acids and their products (Negrón-Mendoza, 1980; Ferradini and Jay-Gerin, 2000). Water radiolysis generates two different species: molecules $\left(\mathrm{H}_{2}\right.$ and $\left.\mathrm{H}_{2} \mathrm{O}_{2}\right)$ and radicals $\left(\bullet \mathrm{H}, \bullet{ }^{\bullet} \mathrm{OH}, \mathrm{e}_{\mathrm{aq}}{ }^{-}\right.$) (Reaction 1 ); these last react with the dissolved molecules and are the main responsible in the formation of products through decomposition, abstraction, dimerization, deprotonation, isomerization and oligomerization reactions (Navarro-González et al., 1990).

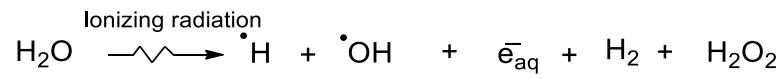

(Reaction 1)
The reaction mechanism of acetic acid radiolysis that has been detailed elsewhere (i.e. Josimović et al., 1976; Negrón-Mendoza, 1980; Navarro-González et al. 1990; Spinks and Woods, 1990) explains the formation of the carboxylic acids identified in this work. Radicals ${ }^{\bullet} \mathrm{H},{ }^{\bullet} \mathrm{OH}$, and $\mathrm{e}_{\mathrm{aq}}{ }^{-}$are the species that react with the acid and produce other molecules. For example, the interaction of radical ${ }^{\bullet} \mathrm{H}$ with the molecule of acetic acid through an abstraction reaction produces molecular hydrogen and a radical $\left({ }^{\bullet} \mathrm{CH}_{2} \mathrm{COOH}\right.$, Radical; see Reaction 2).

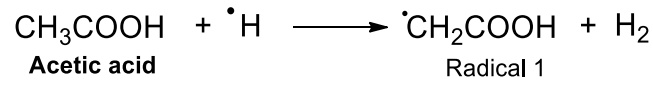

(Reaction 2)

The radical $\bullet^{\bullet} \mathrm{OH}$ also affects the molecule of acetic acid and generates a water molecule and the Radical 1 (Reaction 3).

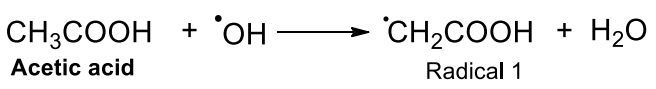

(Reaction 3)

Later, the formation of succinic acid came from the dimerization reaction between ${ }^{\bullet} \mathrm{CH}_{2} \mathrm{COOH}$ radicals (Reaction 4).
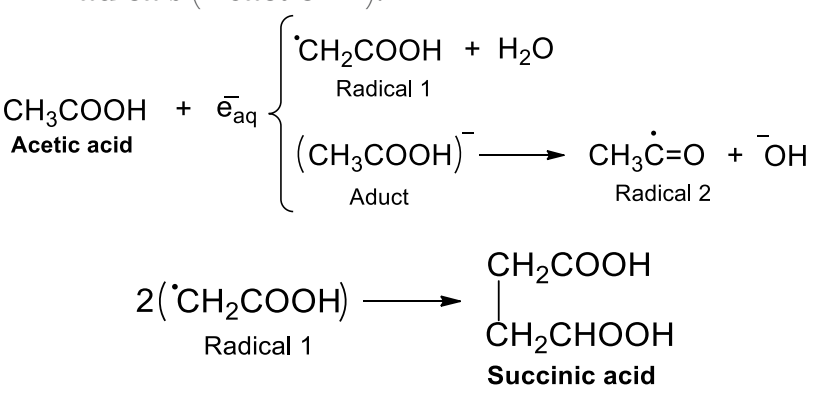

(Reaction 4)

Already formed, succinic acid could react with $\bullet \mathrm{H}$ or ${ }^{\bullet} \mathrm{OH}$ radicals and form the Radical 4, hydrogen and water (Reaction 5).

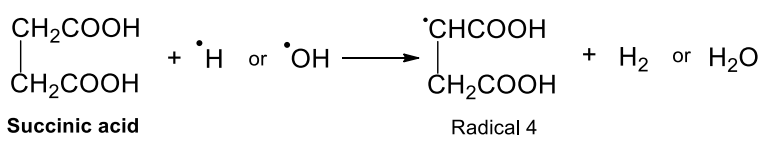

(Reaction 5) 
Radical 1 can also react with other radicals (Radical 4) and form tricarballylic acid (Reaction 6).

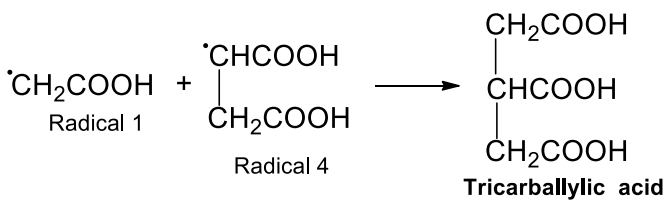

(Reaction 6)

The trycarballylic acid reacts with the radicals ${ }^{\bullet} \mathrm{H}$ or ${ }^{\bullet} \mathrm{OH}$ and forms other radicals (Radical 5 and 6; see Reaction 7).

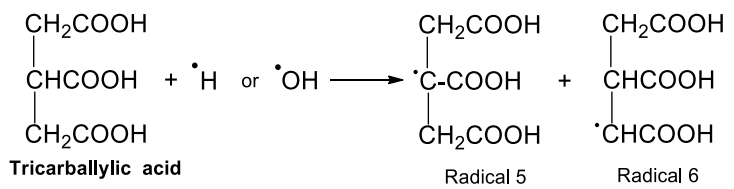

(Reaction 7)

These radicals react with radical $\bullet \mathrm{OH}$ and form citric and isocitric acids (Reaction 8).

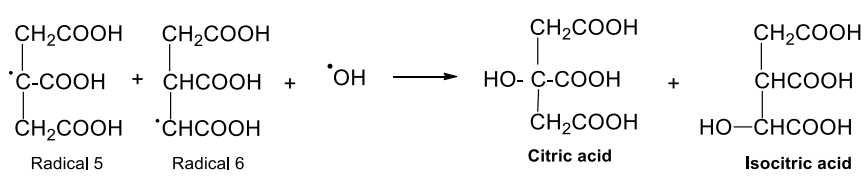

(Reaction 8)

Decarboxylation is one of the most common ways of breaking down carboxylic acids (CruzCastañeda et al., 2014; Cruz-Castañeda, 2019). The decarboxylation of acetic acid leads to the formation of $\mathrm{CO}_{2}$ and $\mathrm{CH}_{4}$; even if it was not possible to quantify their formation in our experiments, we observed the formation of gas bubbles in the samples, probably related to the production of those gases. The formation of $\mathrm{CO}_{2}$ could explain the formation of carboxisuccinic acid.

Criquet and Leitner (2011) studied the radiolysis of acetic acid at variable doses up to $5 \mathrm{kGy}$. These authors highlight that $\mathrm{pH}$ has an effect in decomposition; at $\mathrm{pH} 4.5$ the greatest degradation was observed due to the reaction rate constant between acetate and hydroxyl radicals. Interestingly, in the system studied by Criquet and Leitner (2011) they suggest that acetic acid is attacked mainly by the hydroxyl radical. This reaction could produce oxalic acid, which is extremely reactive and difficult to detect in such system (Carota et al., 2015; Botta et al., 2017).

Formic acid. Like acetic acid, its decomposition by radiolysis has been studied in different experiments (Adams and Hart, 1962; Neta et al., 1969; Ayscough et al., 1971; Josimović and Draganić, 1973; Spinks and Woods, 1990). The irradiation of solutions of formic acid, $\left(10^{-4}\right.$ to $10^{-2}$ $\mathrm{mol} \cdot \mathrm{L}^{-1}$ ) with gamma rays, produces $\mathrm{CO}_{2}$ and $\mathrm{H}_{2}$ as unique gaseous products, and in equal yields (Fricke et al., 1938). In this research, the formation of those gases was not followed, since we were interested in the formation of other carboxylic acids. It is well documented that the preferred route of decomposition of formic acid is by decarboxylation, and $\mathrm{H}_{2}$ is the main reaction product (Fricke et al., 1938; Buxton and Sellers, 1972).

The complexity in the identification of products in the case of formic acid is related to the reactivity of the formed molecules. The radiolysis of formic acid produces formaldehyde (López-Islas et al., 2018), oxalic acid, glyoxal, and glyoxylic acid (oxoacetic) (Garrison et al.,1956). The possible mechanisms that explain the formation of the identified products in this research is the following.

The $\bullet \mathrm{H}$ and $\bullet \mathrm{OH}$, formed from water radiolysis, and formic acid react by an abstraction reaction (Hart, 1951; 1952; 1954a; 1954b). As a result, the radical ${ }^{\bullet} \mathrm{COOH}$ (Radical 7 ) is formed (Reaction 9).

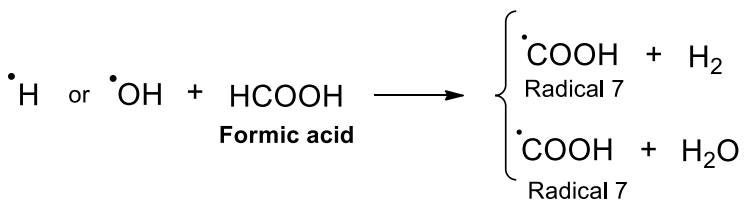

(Reaction 9)

The ${ }^{\bullet} \mathrm{COOH}$ is essential for the formation of some of the identified products. Oxalic acid results from the dimerization reaction of this radical (Reaction $10)$.

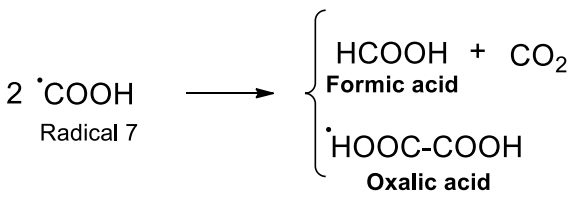

(Reaction 10) 
The ${ }^{\bullet} \mathrm{H}$ species of water, can also react with formic acid, but in this case it subtracts an $\mathrm{OH}$ from the molecule; in consequence, the $\bullet$ HCO radical and molecular water are formed (Reaction 11).

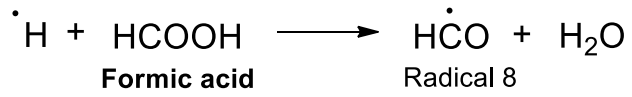

(Reaction 11)

The ${ }^{\bullet} \mathrm{HCO}$ radical is important since it determines the formation of formaldehyde and glyoxilic acid (Juppe et al., 1968; Spinks and Woods, 1990). The radical $\bullet \mathrm{HCO}$ reacts with formic acid $(\mathrm{HCOOH})$, and leads to the formation of formaldehyde and other radical $\left({ }^{\bullet} \mathrm{COOH}\right.$, see Reaction 12$)$.

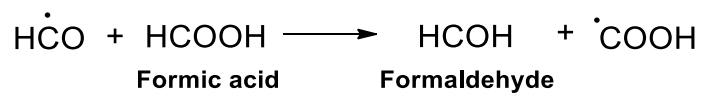

(Reaction 12)

This radical $\left({ }^{\bullet} \mathrm{COOH}\right)$ and the ${ }^{\circ} \mathrm{HCO}$ react to form glyoxylic acid (Reaction 13).

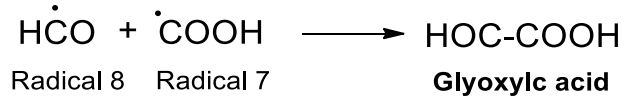

(Reaction 13)

Although, formaldehyde is a highly volatile chemical compound (Atkins and de Paula, 2008) its formation was observed by HPLC (by co-injection), unfortunately we could not quantify it. An interesting point is that formic acid can be regenerated from formaldehyde, a highly reactive intermediate (Smithies and Hart, 1960; López-Islas et al., 2018).

Once glyoxylic acid is formed (Reaction 13), it can react with ${ }^{\bullet} \mathrm{H}$ and form glycolic acid. This last then reacts with Radical 7, forming tartronic acid (Reaction 14).
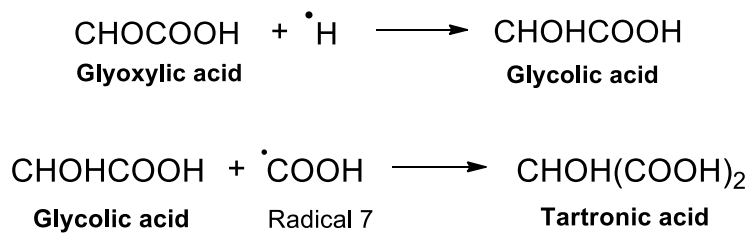

(Reaction 14)
Effect of the mineral on radiolysis of the organic acids. The presence of the mineral affects the decomposition of both molecules. In the case of acetic acid, the decomposition in presence of olivine is smaller than in samples irradiated without the mineral. In the case of formic acid, decomposition is accelerated in presence of the mineral. Accordingly, the mineral plays a fundamental, albeit opposite, roles in the radiolysis of organic acids.

When gamma radiation (up to $1 \mathrm{kGy}$ ) interacts with olivine, a series of changes in the mineral occurs, and some of them affect the volume of the unit cell, such as lattice vibrations and small deformations (Kądziołka-Gaweł et al., 2018). In our experiments, the dose was much higher (up to $184 \mathrm{kGy})$ than in the work of Kądziołka-Gaweł et al. (2018); in consequence, the effects in olivine, reported by such authors, are possible in this case as well. The continuous irradiation also generates amorphization of olivine (Demyk et al., 2001; Carrez et al., 2002). Such changes are probably responsible for energy attenuation. When ionizing energy interacts with water and the organics, the mineral has already experienced the effect of radiation, which would partially account for the reduction in decomposition of acetic acid in solution.

The occurrence of other phenomena is also possible in the studied systems, including Fenton reactions and radical formation on silicate surfaces. Fenton reactions occur when ferrous iron $\left(\mathrm{Fe}^{2+}\right)$ and hydrogen peroxide $\left(\mathrm{H}_{2} \mathrm{O}_{2}\right)$ interact in acidic solution producing ferric iron $\left(\mathrm{Fe}^{3+}\right)$, the hydroxyl radical $\left(\bullet^{\bullet} \mathrm{OH}\right)$ and hydroxyl ion $(-\mathrm{OH})$ (Barb et al. 1949, 1951a and 1951b in Pignatello et al., 2006; Reaction 15).

$\mathrm{Fe}^{+}+\mathrm{H}_{2} \mathrm{O}_{2} \longrightarrow \mathrm{Fe}^{3+}+\mathrm{H}_{2} \mathrm{O}_{2}+{ }^{-} \mathrm{OH}+{ }^{\circ} \mathrm{OH}$

(Reaction 15)

Fenton reactions could effectively occur in the studied systems, as iron $\left(\mathrm{Fe}^{2+}\right)$ is abundantly found in olivine, and $\mathrm{H}_{2} \mathrm{O}_{2}$ is already formed by water radiolysis. The $\bullet \mathrm{OH}^{2}$ radical could later react with organic compounds, as mentioned above, through $\mathrm{H}$ abstraction. In the case of acetic and formic 
acids, $\mathrm{H}$ can be taken from $\mathrm{OH}^{-}$bonds in both carboxylic acids, or from C-H bonds in acetic acid (Reaction 16).

\section{${ }^{\circ} \mathrm{OH}+\mathrm{HCOOH}$ Formic acid

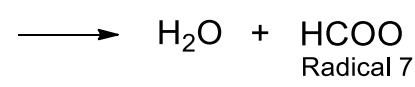 \\ $\cdot \mathrm{OH}+\mathrm{CH}_{3}-\mathrm{COOH}$ \\ Acetic acid

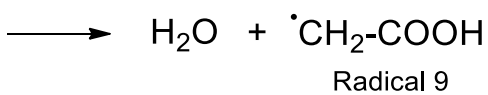

(Reaction 16)

The reaction between the hydroxyl radical and the organic acid depends on the rate of reaction. The reaction between hydroxyl radical and formic acid is faster $\left(k=1.6 \times 10^{8} \mathrm{dm}^{3} \mathrm{~mol}^{-1} \mathrm{~s}^{-1}\right.$ at acidic $\mathrm{pH}$, Jolly et al., 1986) than the reaction rate with acetic acid $\left(k=2.3 \times 10^{7} \mathrm{dm}^{3} \mathrm{~mol}^{-1} \mathrm{~s}^{-1}\right.$ at $\mathrm{pH} 2$; Dorfman and Adams, 1973), at least in one order of magnitude. Through Fenton reactions more ${ }^{\bullet} \mathrm{OH}$ radicals are produced in the medium, and this production could affect the velocity rate of decomposition of organic acids. If the mineral acts as an additional source of hydroxyl radicals, besides water, this could explain why formic acid decomposes faster in presence of olivine than acetic acid.

According to García-Guinea, et al. (2017), ionizing radiation also induces the formation of hydroxyl groups by dissociation of water film. Hydroxyl groups easily bond metals on the surface of the mineral, and metal cations improve the wettability of the mineral surface. This interaction is important, since olivine is rich in metals like $\mathrm{Mg}$, $\mathrm{Fe}$ and $\mathrm{Si}$. In the olivine sample $\mathrm{Cr}, \mathrm{Ni}$, and $\mathrm{Mn}$ are also found, and Mn could largely contribute to this behavior.

Another mechanism, such as the radical formation on silicate surfaces, involves the behavior of the mineral as a semiconductor. When a semiconductor is exposed to ionizing radiation the energy interacts with the solid. High energy radiation excites the solid (Zacheis et al., 1999), thus producing the ionization of the solid and the transfer of the excitation energy to adsorbates. Ionizing radiation induces the promotion of some electrons from the valence to the conduction band, generating positive holes $\left(\mathrm{h}^{+}\right)$in the valence bands, a process called charge separation. The holes $\left(\mathrm{h}^{+}\right)$ and electrons can recombine or migrate to the surface, where they can be trapped or react with the adsorbed species (Thomas, 1993). Adsorbates can scavenge electrons or donate electrons to the holes through transfer processes. In general, the radiolysis of solids containing adsorbates produces ionic products and free radicals (Zacheis et al., 1999).

Even if there is not a precise mechanism for olivine, there are studies that describe such processes for other silicates. In the case of silica gel, the homolytic scission of bonds in the surficial $\mathrm{OH}$-groups leads to the formation of very reactive hydrogen stabilized on the surface layer (Kazansky et al., 1961). This radical can later react with organics (Reaction 17).

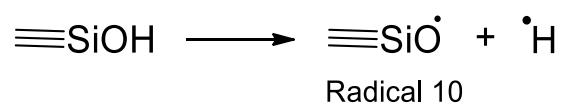

(Reaction 17)

Olivine as an anhydrous mineral does not harbor hydrogen on its structure. Nonetheless, there has been demonstrated that hydrogen is already incorporated into the mineral (Bai and Kohlstedt 1992, 1993, Kohlstedt et al., 1996; Kohlstedt and Mackwell 1998, 1999). Hydrogen could be associated with defects on the lattice (i.e. oxygen interstitials, magnesium vacancies, Bai and Kohlstedt 1992, 1993). Natural conditions could determine the incorporation of hydrogen in olivine, among them pressure, temperature, and iron content (Zhao et al., 2004) since they affect hydrogen solubility. Having this into account, the production of radical $\bullet \mathrm{H}$ from olivine under irradiation is highly possible.

The reaction between the $\cdot \mathrm{H}$ radical and formic acid is faster $\left(k=2.1 \times 10^{6} \mathrm{dm}^{3} \mathrm{~mol}^{-1} \mathrm{~s}^{-1}\right)$ than the same abstraction reaction with acetic acid $\left(k=7.5 \times 10^{4} \mathrm{dm}^{3} \mathrm{~mol}^{-1} \mathrm{~s}^{-1}\right)$. This indicates that formic acid is more decomposed by either ${ }^{\bullet} \mathrm{OH}$ or ${ }^{\bullet} \mathrm{H}$ radicals. Since both radicals are present in the system, the reactions may occur at the same time.

One important finding in this research is that olivine affects the formed products both in 
amount and type. Brucato et al. (2006) found that amorphous olivine $\left(\mathrm{MgFeSiO}_{4}\right)$ acts as catalysis and prevents the formation of some functional groups $\left(\mathrm{NH}_{3}\right.$ and $\mathrm{CN}-$ molecules) and changes the relative abundance of others $\left(\mathrm{NH}_{4}^{+}, \mathrm{OCN}^{-}, \mathrm{CO}_{2}\right.$, $\mathrm{HNCO}, \mathrm{CO})$ in proton irradiation experiments of formamide $(200 \mathrm{keV})$. The same authors suggest that this could be related to the charge exchange due to presence of iron and magnesium on the olivine. In the experiments shown here, olivine also acts as a selective catalyst in chemical reactions. In the case of acetic acid, olivine avoids the formation of citric acid, and promotes the formation of carboxisuccinic acid. Regarding the formic acid, the effect was quantitative, since the formed molecules (oxalic and tartronic) are produced at lower amounts (Table 4). In this case, the decomposition of formic acid is higher $\left(\mathrm{G}_{0}=4.13\right)$, but it is not producing other carboxylic acids, probably because the decarboxylation reaction is the dominant path. Hence, we could say that olivine affects organic molecules radiolysis and formed products.

\subsection{THERMOLYSIS}

Acetic acid. In the case of this acid, thermal energy is also very effective in promoting decomposition. On the one hand, the solution of acetic acid showed a decomposition of $63 \%$ after $120 \mathrm{~h}$ of heating (at $95^{\circ} \mathrm{C}$ ). On the other hand in solutions that contained the mineral decomposition was lesser $(54 \%)$. The thermolysis of acetic acid has been largely studied (Blake and Jackson, 1968; Palmer and Drummond, 1986; Bell and Palmer, 1994 and references therein).

In the thermolysis of acetic acid solutions the main reaction that occurs is decarboxylation at relatively low temperatures $\left(<400{ }^{\circ} \mathrm{C}\right)$, both in aqueous solution (Blake and Jackson, 1968) and in presence of minerals, such as magnetite, synthetic pyrite, and Fe-montmorillonite (Bell et al., 1994). This reaction includes a cleavage of the $\mathrm{C}-\mathrm{C}$ bond, between the carbonyl group and the rest of the molecule (Bell et al., 1994). The main products of decarboxylation are methane and carbon dioxide (Reaction 18).

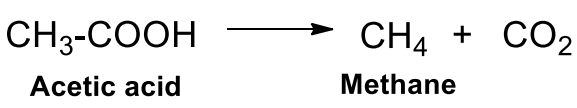

(Reaction 18)

The decarboxylation of most carboxylic acids occurs as homogeneous reactions at relatively low temperatures; acetic acid seems relatively stable to decomposition, since it is an aliphatic monocarboxylic acid, and spontaneous unimolecular decomposition does not take place easily (Bell et al., 1994). It has been suggested that acetic acid could exist in a metastable state, with respect to their decomposition products (Bell et al., 1994). If the reaction proceeds at high temperatures, and therefore acetic acid is in vapor phase, ketene and water are also formed, in a competing reaction to methane and carbon reaction (Mackie and Doolan, 1984).

Formic acid. Formic acid decomposes when heated in both oxidative and non-oxidative conditions (Bjerre and Soerensen, 1992). It has been observed that this molecule decomposes by two possible pathways decarboxylation and dehydration (Akiya and Savage, 1998) Reactions 19 and 20.

$\mathrm{HCOOH} \longrightarrow \mathrm{CO}_{2}+\mathrm{H}_{2}$ decarboxylation Formic acid

(Reaction 19)

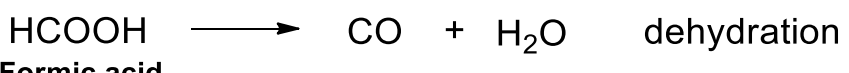

Formic acid

(Reaction 20)

Water largely influences the pathway of decomposition, and in the presence of the water decarboxylation is more favorable (Akiya and Savage, 1998), in the absence of water dehydration accomplishes. At temperatures above $300{ }^{\circ} \mathrm{C}$ the main products are $\mathrm{CO}_{2}$ and $\mathrm{H}_{2}$, which suggests decarboxylation could be the preferred pathway for the decomposition of formic acid under hydrothermal conditions (Yu and Savage, 1998).

Most of the products formed by the decomposition of formic acid are gases. However, other 
molecules are also produced by the thermolysis of formic acid. According to Nelson and Engelder (1926), in addition to the abundant formation of $\mathrm{CO}_{2}$ and $\mathrm{H}_{2}$ gases, there is formaldehyde production at temperatures below $250{ }^{\circ} \mathrm{C}$. This last molecule is formed during the $\mathrm{CO}_{2}$ condensation process (Reaction 21).

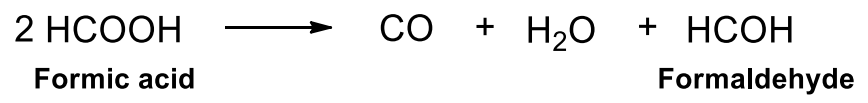

(Reaction 21)

Through the secondary decomposition of formaldehyde, $\mathrm{CO}$ is also produced. (Nelson and Engelder, 1926; Wescott and Engelder, 1926). In addition, carboxylic acids are also formed from formic acid thermolysis. In our experiments, the formation of other carboxylic acids was followed, based on the premise that conditions on HVS could have allowed the diversification of organic matter. Two organic acids were detected: oxalic and tartronic.

Effect of the mineral on thermolysis of the organic acids. There is also an effect of mineral in the decomposition of both acids. In both systems, olivine induces less decomposition; in the case of acetic acid the recovered acid was $46 \%$; and in the case of formic acid, $57 \%$ of the organic acid was recovered after heating. Even if the exact mechanism is not known, olivine affects decomposition.

In experiments, simulating hydrothermal conditions acetic acid decomposes, and decarboxylation reaction is favored in the presence of a catalyst (Bell et al., 1994). Different catalytic surfaces have been tested, including stainless steel vessels (Kharaka et al., 1983), titanium, silica, stainless steel, gold, and magnetite (Palmer and Drummond, 1986); from these studies different activation energies, dependent on the employed surface, were calculated. Stainless steel, silica, and magnetite showed clear catalytic effects (Palmer and Drummond, 1986).

When olivine is exposed to high temperatures $\left(400-1180{ }^{\circ} \mathrm{C}\right.$ ) in air it experiences changes; in particular $\mathrm{Fe}^{3+}$ is a major product at $1000{ }^{\circ} \mathrm{C}$
(Kądziołka-Gaweł et al., 2019). These changes cannot occur at low temperatures and pressures, such as those in this study. Nonetheless, it has been proposed that iron, present on surfaces, could facilitate the decarboxylation and participate in oxidation of acetic acid (Bell et al., 1994). Formic acid could be metastable (in hydrothermal settings) with respect to their products, due to a high activation energy barrier, that inhibits the spontaneous decomposition (Bell and Palmer, 1994). In a computer simulation study, Laporte et al. (2020) found that mineral (magnesia $\mathrm{MgO}, 001$ ) could modify the chemical equilibrium, favoring the formation of formic acid from carbon monoxide and water, just by proximity (Laporte et al., 2020). In this study Laporte et al. (2020) suggest that the mineral/water interface favors the formation (displacing the equilibrium reaction) of the carboxylic acid. This could explain why the amount of carboxylic acids is higher in samples containing olivine, compared with those heated without the mineral.

\section{Relevance in prebiotic chemistry stud-} ies. Nowadays, HVS are extremely complex systems and there converge many geochemical conditions, including different energy sources. In order to have a better understanding of the role that these systems could have played on prebiotic chemistry, it is necessary to design simple prebiotic experiments. In this study, the participation of two different energy sources on the decomposition of organic acids, and the formation of other carboxylic acids was evaluated. Both sources (radiation and heating) induce the decomposition and promote the formation of other carboxylic acids, but the effect is very different. According to our results, ionizing radiation induces a greater decomposition on the carboxylic acids, compared to the effect of thermal energy, in percentage. This fact is relevant since HVS are questioned as reasonable sites for the synthesis and stability of prebiotic molecules, due to the high temperatures hosted by them. However, as shown here, other energy sources could be as effective on promoting changes in organic matter as heat, and it is essential to explore them. 
The temperature here essayed $\left(95{ }^{\circ} \mathrm{C}\right)$ is relatively low, compared to the maximum found in submarine hydrothermal systems (up to $350{ }^{\circ} \mathrm{C}$ ). However, it is necessary to remind that on natural HVS temperature gradients are present, both in space and time; in other words, high temperatures are neither static nor uniform across a system. Those temperature gradients could have provided the necessary energy flux for prebiotic chemical reactions (Colín-García et al., 2016 and references therein). In addition, other hydrothermal systems (like subaereal) hold milder conditions, such as less temperature and pressure, and must be also considered as essential in the prebiotic scenario. Importantly, in our experiments, at relatively low constant temperature, the formation of other organic acids was confirmed. As many variables play a key role in hydrothermal systems, we consider that careful and systematic experiments could help to understand the specific role that each one could have played in those systems. Even at harsh conditions, organic synthesis was accomplished in such geological environments; so, it is likely that reactions occurred on HVS could have contributed to prebiotic chemistry on Earth.

\section{Conclusions}

Hydrothermal systems hold conditions that could have favored the synthesis of organic compounds relevant for chemical evolution. Energy sources and mineral gradients are conspicuous on contemporary environments. In this research, ionizing and thermal energy induced chemical changes in carboxylic acids. However, radiation was more effective in promoting decomposition than thermal energy. As well, olivine, played a key role in the decomposition of organic molecules in both radiolysis and thermolysis. Although, the exact mechanism is not known, the participation of solids in the reactions occurs-promoted by ionizing radiation or heat, and it affects the formation of other organic molecules.

It is necessary to consider the complexity of the environments in order to evaluate them as feasible environments for prebiotic synthesis. According to our results, hydrothermal systems are environments where organic molecules could have experienced many reactions; this could have increased the inventory of molecules on primitive Earth.

\section{Acknowledgements}

This article constitutes a part of the $\mathrm{Ph}$. D. of the first author. LAGL acknowledges the CONACyT for a Ph.D. grant and to Posgrado en Ciencias de la Tierra, UNAM. The authors want to express their gratitude to Benjamin Leal Acevedo and Francisco García Flores (Instituto de Ciencias Nucleares, UNAM) for their assistance in irradiation experiments; to Carlos Linares-López (Instituto de Geofisica) for olivine characterization, and to Claudia Camargo for her technical help in the Lab. ANM acknowledges the support of DGAPA-PAPIIT grant (110919). This research was possible thanks to the financial support of DGAPA-PAPIIT (IN111720) and CONACyT (A1-S-25341) grants. The Instituto de Geología (UNAM), Instituto de Geofísica (UNAM), and Instituto de Giencias Nucleares (UNAM) are acknowledged for the use of their facilities.

\section{References}

Adams, G.E., Hart, E.J., 1962, Radiolysis and photolysis of aqueous formic acid. Carbon monoxide formation: Journal of the American Chemical Society, 84, 3994-3999. https://doi.org/10.1021/ja00880a003

Akiya, N., Savage, P.E., 1998, Role or water in formic acid decomposition: American Institute of Chemical Engineers Journal, 44, 405-415. https://doi.org/10.1002/ aic.690440217

Atkins P.W., de Paula, P.W., 2008, Atkins Physical Chemistry, $8^{\text {th }}$ edition, W. H. Freeman, New York : Oxford University Press, 881 p.

Ayscough, P.B., Mach, K., Oversby, J.P., Roy, A.K., 1971, Electron spin resonance studies 
of fundamental processes in radiation-and photo-chemistry, Part 6. The radiolysis of acetic acid: Transactions of the Faraday Society, 67, 360-374.

Bai, Q., Kohlstedt, D.L., 1992, Substantial hydrogen solubility in olivine and implications for water storage in the mantle: Nature, 357, 672-674. https://doi. org/10.1038/357672a0

Bai, Q., Kohlstedt, D.L., 1993, Effects of chemical environment on the solubility and incorporation mechanism for hydrogen in olivine: Physics and Chemistry Minerals, 19, 460-471. https://doi.org/10.1007/ BF00203186

Ballard, R.D., 1977, Notes on a Major Oceanographic Find: Oceanus, 20, 35-44.

Baross, J.A., Hoffman, S.E., 1985, Submarine hydrothermal vents and associated gradients environments as sites for the origin and evolution of life: Origins of Life and Evolution of the Biosphere, 15, 227-245. https://doi.org/10.1007/BF01808177

Bell, J.L.S., Palmer, D.A. 1994, Experimental studies of organic acid decomposition, In Lewan, M. D. and Pittman, E. D. (Eds.), The Role of Organic Acids in Geological Processes, Springer Verlag, 226-269.

Bell, J.L.S., Palmer,D.A., Barnes,H.L.,Drummond, S.E, 1994, Thermal decomposition of acetate: III. Catalysis by mineral surfaces: Geochemica et Cosmochimica Acta, 58(19), 4155-4177. https://doi. org/10.1016/0016-7037(94)90271-2

Bernal, J.D., 1951, The Physical Basis of Life, London: Routledge and Kegan Paul, 300-364.

Bjerre, A.N., Soerensen, E., 1992, Thermal decomposition of dilute aqueous formic acid solution: Industrial Engineering Chemistry Research, 31, 1574-1577. https://doi. org/10.1021/ie00006a022

Blake, P.J., Jackson, G.E., 1968, The thermal decomposition of Acetic Acid: Journal of the Chemical Society B: Physical Organic, 608, 1153-1155. https://doi.org/10.1039/

\section{J29680001153}

Bonner, W.A., Kavasmaneck, P.R., Martin, F.S., Flores, J. J., 1975, Asymmetric adsorption by quartz: A model for the prebiotic origin of optical activity: Origins of Life, 6(3), 367376. https://doi.org/10.1007/BF01 130338

Botta, L., Bizzarri, B. M., Piccinino, D., Fornaro, T., Brucato, J. R., Saladino, R., 2017, Prebiotic synthesis of carboxylic acids, amino acids and nucleic acid bases from formamide under photochemical conditions: The European Physical Journal Plus, 132, 1-7. https://doi. org/10.1140/epjp/i2017-11631-5

Brucato, J.R., Strazzulla, G., Baratta, G.A., Rotundi, A., Colangeli, L., 2006, Cryogenic synthesis of molecules of astrobiological interest: Catalytic role of cosmic dust analogues: Origins of Life and Evolution of Biospheres, 36, 451-457. https://doi. org/10.1007/s1 1084-006-9050-5

Burr, J.G., 1957, A Comparison of the Radiolysis and Mass Spectrometry of Several Deuterated Ethanols: Journal of the American Chemical Society, 79, 751-752. https://doi.org/10.1021/ja01560a070

Buxton, G.V., Sellers, R.M., 1972, Acid dissociation constant of the carboxyl radical. Pulse radiolysis studies of aqueous solutions of formic acid and sodium formate, Cookride High Energy Radiation Research Centre, University of Leeds, Cookridge Hospital, 555-559. https://doi.org/10.1039/ F19736900555

Calvin, M., 1956, Chemical Evolution and Origin of Life, Sigma Xi, The Scientific Research Honor Society: American Scientist, 44, 248-263.

Carota, E., Botta G., Rotelli, L., Di Mauro, E., Saladino, R., 2015, Current Advances in Prebiotic Chemistry Under Space Conditions: Current Organic Chemistry 19(20), 1963-1979. https://doi.org/10.2174 /1385272819666150622175143

Carrez, P., Demyk, K., Cordier, P., Gengembre, L., Grimblot, J., D'Hendecourt, L, Jones, A.P., Leroux, H., 2002, Low-energy helium ion irradiation-induced amorphization 
and chemical changes in olivine: Insights for silicate dust evolution in the interstellar medium: Meteoritics and Planetary Science, 37, 1599-1614. https://doi. org/10.1111/j.1945-5100.2002.tb00814.x

Cody, G.D., Boctor, N.Z., Hazen, R.M., Brandes, J.A., Morowitz, H.J., Yoder, Jr. H.S., 2001, Geochemical roots of autotrophic carbon fixation: hydrothermal experiments in the system citric acid, $\mathrm{H}_{2} \mathrm{O}-( \pm \mathrm{FeS})-( \pm \mathrm{NiS})$ : Geochimica et Cosmochimica Acta, 65, 3557-3576. https://doi.org/10.1016/ S0016-7037(01)00674-3

Colín-García, M., Heredia, A., Cordero, G., Camprubí, A., Negrón-Mendoza, A., Ortega-Gutiérrez, F., Beraldi, H., RamosBernal, S., 2016, Hydrothermal vents and prebiotic chemistry: a review: Boletín de la Sociedad Geológica Mexicana 68, 599-620. http://dx.doi.org/10.18268/ BSGM2016v68n3a13

Colín-García,M., Villafañe-Barajas, S., Camprubí, A., Ortega-Gutiérez, F., Colás, V., NegrónMendoza, A., 2018, Prebiotic chemistry in hydrothermal vent systems, in Vera, M. Kolb (Ed.). Handbook of Astrobiology, Cap. 5.4. Taylor \& Francis Group, CRC Press. https:// doi.org/10.1201/b22230-21

Corliss, J.B., Baross, J.A., Hoffmann, S.E., 1980, Submarine Hydrothermal Systems: A Probable Site for the Origin of Life, School of Oceanography, Oregon State University, 1-44 pp.

Corliss, J.B., Baross, J.A., Hoffmann, S.E., 1981, An hypothesis concerning the relationship between submarine hot springs and the origin of life on Earth, Oceanologica Acta. Actes $26^{\circ}$ Congrès International de Géologie, colloque Géologie des océans, Paris, 59-69. https:// archimer.ifremer.fr/doc/00245/35661/

Criquet, J., Leitner, N.K.V., 2011, Radiolysis of acetic acid aqueous solutions - Effect of $\mathrm{pH}$ and persulfate addition: Chemical Engineering Journal, 174, 504-509. https:// doi.org/10.1016/j.cej.2011.07.079

Cruz-Castañeda, J.A., 2019, Estabilidad de algunas bases nitrogenadas en un sistema que simula una ventila hidrotermal, Universidad Nacional Autónoma de México,Posgrado en Ciencias Químicas, Tesis Doctoral, 97 p.

Cruz-Castañeda, J.A., Negrón-Mendoza, A., Frías, D., Golín-García, M., Heredia, A., Ramos-Bernal, S., Villafañe-Barjas, S.A., 2014, Chemical evolution studies: the radiolysis and thermal decomposition of malonic acid: Journal of Radioanalytical Nuclear Chemistry 304, 219-225. https:// doi.org/10.1007/s10967-014-3711-z

Dana, E.S., Ford, W.E., Berumen, A., 1979, Tratado de Mineralogía: Con un extenso sobre cristalografía y mineralogía física, $4^{\mathrm{a}}$ edición, Compañía Editorial Continental, México, 30-180.

Deer, W.A., Hawie, R.A., Zussman, J., 1982, Rock forming minerals. Orthosilicates, 1A. Second edition. Published by The Geological Society, $352 \mathrm{p}$.

Demyk, K., Carrez, P., Leroux, H., Cordier, P., Jones, A.P., Borg, J., Quirico, E., Raynal, P.I., d'Hendecourt, L., 2001, Structural and chemical alteration of crystalline olivine under low energy He+ irradiation: Astronomy and Astrophysics, 368, L38-L41. https:// doi.org/10.1134/S1066362209010093

Dorfman, L.M., Adams, G.E., 1973, Reactivity of the hydroxyl radical in aqueous solutions, (No. NSRDS-NBS-46). National Standard Reference Data System, 59 p.

Draganić, I.G., Draganić, D.Z., 1978, Radiactivity and Radiation Chemistry on the Early Earth. In. C. Archundia (Ed.). Plenary Lectures Symposium on Nuclear Chemistry, Radiochemistry and Radiation Chemistry", México D. F. 50-72 p.

Draganić, I.G., Bjergbakke, E., Draganić, Z.D., Sehested, K., 1991, Decomposition of ocean waters by potassium-40 radiation 3800 Ma ago as a source of oxygen and oxidizing species: Precambrian Research, 52, 337-345. https://doi. org/10.1016/0301-9268(91)90087-Q

Ferradini, G., Jay-Gerin, J.P., 2000, The effect of 
$\mathrm{pH}$ on water radiolysis: A still open question - A minireview: Research on Chemical Intermediates, 26, 549-565. https://doi. org/10.1163/156856700X00525

Ferris, J.P., 1992, Chemical markers of prebiotic chemistry in hydrothermal systems, Chapter 6: Origins of Life and Evolution of Biospheres, 22, 109-134. https://doi. org/10.1007/BF0 1808020

Ferris, J.P., 2005, Mineral Catalysis and Prebiotic Synthesis: MontmorilloniteCatalyzed Formation of RNA: Elements, 1, 145-149. https://doi.org/10.2113/ gselements.1.3.145

Fricke H., Hart E.J., Smith H.P., 1938, Chemical reactions of organic compounds with X-Ray activated water: Journal of Chemical Physics, 6, 229-240. https://doi. org/10.2307/3571091

García-Guinea, J., Garrido, F., Lopez-Arce, P., Correcher, V., de la Figuera, J., 2017, Spectral green cathodoluminescence emission from surfaces of insulators with metal-hydroxyl bonds: Journal of Luminescence, 190, 128-135. https://doi. org/10.1016/j.jlumin.2017.05.039

Garrison, W.M., Bennet, W., Jayko, M., 1956, Mechanism in the radiolysis of aqueous formic acid solutions: Journal of Chemical Physics 24,631-632. https://doi. org/10.1063/1.1742579

Garzón, L., Garzón, M.L., 2001, Radioactivity as a significant energy source in prebiotic synthesis: Origin of Life and Evolution of Biosphere, 31, 3-13. https://doi. org/10.1023/A:1006664230212

Gordeev, A.V., Kosareva, I.M., Bykov, G.L., Ershov, B.G., 2007, Simulation of the Radiation-Chemical Transformations of Acetic Acid in Aqueous Solutions: High Energy Chemistry, 41, 233-238. https://doi. org/10.1134/S0018143907040030

Guzman, M.I., Martin, S.T., 2009, Prebiotic metabolism: production by mineral photoelectrochemistry of a-ketocarboxylic acids in the reductive tricarboxylic acid cycle:
Astrobiology, 9(9), 833-842. https://doi. org/10.1089/ast.2009.0356

Hart, E.J., 1951, Mechanism of the $\gamma$-Ray-Induced Oxidation of Formic Acid in Aqueous Solution: Journal of American Chemical Society, 73, 68-73. https://doi.org/10.1021/ ja01145a026

Hart, E.J., 1952, The Radical Pair Yield of Ionizing radiation in Aqueous Solutions of Formic Acid: The Journal of Physical Chemistry, 56, 594. https://doi.org/10.1021/j150497a009

Hart, E.J., 1954a, $\gamma$-Ray-Induced Oxidation of Aqueous Formic Acid-Oxygen Solutions. Effect of Oxygen and Formic Acid Concentration: Journal of the American Chemical Society, 76, 4312-4315. https:// doi.org/10.1021/ja01646a016

Hart, E.J., 1954b, $\gamma$-Ray-Induced Oxidation of Aqueous Formic Acid-Oxygen Solutions. Effect of $\mathrm{pH}$ : Journal of the American Chemical Society, 76, 4198-4201. https:// doi.org/10.1021/ja01645a056

Hashizume, H., 2012, Role of clay minerals in chemical evolution and the origins of life, Chapter 10, In: Valaškova M and Martynkova GS (eds) Glay minerals in nature-their characterization. Intech Open, 191-208. http://dx.doi.org/10.5772/50172

Hashizume, H., 2015, Adsorption of nucleic acid bases, ribose, and phosphate by some clay minerals: Life, 5, 637-650. https://doi. org/10.3390/life5010637

Jolly, G.S., McKenney, D.J., Singleton, D.L., Paraskevopoulos, G., Bossard, A.R., 1986, Rates of hydroxyl radical reactions. Part 14. Rate constant and mechanism for the reaction of hydroxyl radical with formic acid: The Journal of Physical Chemistry, 90(24), 6557-6562. https://doi.org/10.1021/ j100282a028

Josimović, L., Draganić, I., 1973, The radiolysis of acetic acid in aqueous solutions and acetic acid-water mixtures: International Journal for Radiation Physics and Chemistry, 5, 505-512. https://doi. org/10.1016/0020-7055(73)90013-2 
Josimović, L., Teplý, J., Mićić, O.I., 1976, Radiolysis of carboxylic compounds. Part 2. Radiolysis of liquid acetic acid: Journal of the Chemical Society, Faraday Transactions 1: Physical Chemistry in Condensed Phases, 72, 285-289. https://doi.org/10.1039/ F19767200285

Juppe, G., Kolmar, H., Fantechi, R., 1968, High Dose Integrating Chemical Dosimeters. The radiolysis of aqueous sodium formate solutions: European Atomic EnergyEuratom. Printed by Guyot, S. A. Brussels, 5-12.

Kądziołka-Gaweł, M., Adamczyk, Z., Kalinowski, L., 2019, Mössbauer Study of Changes in Olivine After Heating in Air: The Canadian Mineralogist, 57, 105-115. https://doi. org/10.3749/canmin. 1700074

Kądziołka-Gaweł, M., Dulski, M., Kalinowski, L., Wojtyniak, M., 2018, The effect of gamma irradiation on the structural properties of olivine: Journal of Radioanalytical and Nuclear Chemistry, 317, 261-268. https:// doi.org/10.1007/s10967-018-5849-6

Kamenetsky, V.S., Sobolev, A.V., Eggins, S.M., Crawford, A.J., Arculus, R.J., 2002, Olivineenriched melt inclusions in chromites from low-Ca boninites, Cape Vogel, Papua New Guinea: evidence for ultramafic primary magma, refractory mantle source and enriched components: Chemical Geology, 183, 287-303. https://doi.org/10.1016/ S0009-2541(01)00380-1

Kazansky, V.B., Pariisky, G.B., Voevodsky, V.V., 1961, Radiation-induced processes on the silica-gel surface: Discussions of the Faraday Society, 31, 203-208. https://doi. org/10.1039/DF9613100203

Kharaka, Y.K., Carothers, W.W., Rosenbauer, R.J., 1983, Thermal decarboxylation of acetic acid: Implications for origin of natural gas: Geochimica et Cosmochimica Acta, 47, 397-402. https://doi. org/10.1016/0016-7037(83)90262-4

Kitadai, N., Maruyama, S., 2018, Origins of building blocks of life: A review: Geoscience
Frontiers, 9, 117-1153. https://doi. org/10.1016/j.gsf.2017.07.007

Kohlstedt, D.L., Keppler, H., Rubie, D.C., 1996, Solubility of water in the $\mathrm{a}, \mathrm{b}$ and $\mathrm{c}$ phases of $(\mathrm{Mg}, \mathrm{Fe})_{2} \mathrm{SiO}_{4}$ : Contributions to Mineralogy and Petrology, 123, 345-357. https://doi. org/10.1007/s004100050161

Kohlstedt, D.L., Mackwell, S.J., 1998, Diffusion of hydrogen and intrinsic point defects in olivine: Zeitschrift für Physikalische Chemie, 207, 147-162. https://doi.org/10.1524/ zpch.1998.207.part_1_2.147

Kohlstedt, D.L., Mackwell, S.J., 1999, Solubility and diffusion of 'water' in silicate, In Wright K, Catlow R (eds), Microscopic properties and processes in minerals. Kluwer, Dordrecht, 539-559.

Lahav, N., White, D.H., 1980, A possible role of fluctuating clay-water systems in the production of ordered prebiotic oligomers: Journal of Molecular Evolution, 16, 11-21. https://doi.org/10.1007/BF01732066

Laporte, S., Pietrucci, F., Guyot, F., Saitta, A.M., 2020, Formic Acid Synthesis in a WaterMineral System: Major Role of the Interface: The Journal of Physical Chemistry C, 124, 5125-5131. https://doi.org/10.1021/acs. jpcc.9b09979

Lemmon, R.M., 1970, Chemical Evolution: Chemical Reviews, 70, 95-109. https://doi. org/10.1021/cr60263a003

López-Islas, A., Colín-García, M., NegrónMendoza, A., 2018, Stability of aqueous formaldehyde under $\gamma$ irradiation: prebiotic relevance: International Journal of Astrobiology, 1-6. https://doi.org/10.1017/ S1473550418000368

Lukáč, S., Teplý,J., Vacek, K., 1972, Radiolysis of carboxylic compounds. Part 1.-Comparison of potassium acetate and acetic acid radiolysis: Journal of the Society, Faraday Transactions 1: Physical Chemistry in Condensed Phases, 68, 1377. https://doi. org/10.1039/f19726801377

Mackie, J. C., Doolan, K. R. ,1984, Hightemperature kinetics of thermal 
decomposition of acetic acid and its products: International Journal of Chemical Kinetics, 16, 525-541. https://doi.org/10.1002/ kin. 550160504

Malaterre, C., 2015, Chemical evolution and life. BIO Web of Conferences, 4, 00002. https:// doi.org/10.1051/bioconf/20150400002

McKee, T., McKee, J.R., 2003, Bioquímica: la base molecular de la vida, McGraw-Hill/ Interamericana, 272-560.

Miller, S.L., Urey, H.C., 1959, Organic Synthesis on the Primitive Earth: Science, 130, 245-251. https://doi.org/10.1126/ science.130.3370.245

Navarro-González, R., Negrón-Mendoza, A., Ramos-Bernal, S., Ponnamperuma, C., 1990, Radiolysis of Aqueous Solutions of Acetic Acid in the Presence of Na-Montmorillonite, Proceedings of the ${ }^{9}$ th International Clay Conference, Strasbourg 1989, Sciences Géologiques, Bulletins et Mémories, 85, 55-65.

Negrón-Mendoza, A., 1980, Formación de ácidos policarboxílicos de importancia biológica inducida por radiación ionizante, Universidad Nacional Autónoma de México,Posgrado en Ciencias Químicas, Tesis Doctoral, 175 p.

Negrón-Mendoza, A., Navarro-González, R., 1990, The $\gamma$-irradiation of aqueous acetic - clay suspensions: Origins of Life and Evolution of the Biosphere, 20, 377-387. https://doi.org/10.1007/BF01808132

Negrón-Mendoza, A., Ponnamperuma, C., 1976, Formation of biologically relevant carboxylic acids during the gamma irradiation of acetic acid: Origins of Life, 7, 191-196. https://doi.org/10.1007/ BF00926937

Negrón-Mendoza, A., Ramos-Bernal, S., Mosqueira, F.G., 2004a, Evolución química y el origen de la vida, Profesores al día: Educación Química, 15, 228234. http://dx.doi.org/10.22201/ fq.18708404e.2004.4e.66151

Negrón-Mendoza, A., Ramos-Bernal, S.,
Mosqueira, F.G., 2004b, Synthesis in prebiotic clay environments induced by radiation: International Journal of Astrobiology, 3, 295-300. https://doi.org/10.1017/ S1473550405002193

Nelson, W.L., Engelder, G.J. 1926, The Thermal Decomposition of Formic Acid: Journal of Physical Chemistry, 30, 470-475. https:// doi.org/10.1021/j150262a003

Neta, P., Simic, M., Hayon, E., 1969, Pulse radiolysis of aliphatic acids in aqueous solutions. I. Simple monocarboxylic acids: The Journal of Physical Chemistry, 73, 4207-4213. https://doi.org/10.1021/ j100846a029

O’Donnell, J.H., Sangster, D.F., 1970, Principles of Radiation Chemistry, Elsevier Publishing Company, Amsterdam.

Palmer, D.A., Drummond, S.E., 1986, Thermal decarboxylation of acetate. Part I. The kinetics and mechanism of reaction in aqueous solution: Geochimica et Cosmochimica Acta, 50, 813-823. https:// doi.org/10.1016/0016-7037(86)90357-1

Parsons, I., Lee, M. R., Smith, J. V., 1998., Biochemical evolution II: Origin of life in tubular microstructures on weathered feldspar surfaces: Proceedings of the National Academy of Sciences, 95(26), 15173-15176.

Pignatello, J.J., Oliveros, E., MacKay, A., 2006, Advanced oxidation processes for organic contaminant destruction based on the Fenton reaction and related chemistry: Critical Reviews in Environmental Science and Technology, 36, 1-84. https://doi. org/10.1080/10643380500326564

Pirajno, F., 2009, Hydrothermal processes and mineral systems: East Perth, Australia, Springer, 1250 p. https://doi. org/10.1007/978-1-4020-8613-7_11

Rao, M., Odom, D.G., Oró, J., 1980, Clays in Prebiological Chemistry: Journal of Molecular Evolution, 15, 317-331. https:// doi.org/10.1007/BF01733138

Rimola, A., Mariona, S., Ugliengo, P., 2019, Role of mineral surfaces in Prebiotic 
Chemistry evolution, In Silico Quantum Mechanical Studies: Life, 9, 1-44. https:// doi.org/10.3390/life9010010

Rimola, A., Sodupe, M., Ugliengo, P., 2007, Aluminosilicate surfaces as promoters for peptide bond formation: An assessment of Bernal's hypothesis by ab Initio methods: Journal of the American Chemical Society, 129, 8333-8344. https://doi.org/10.1021/ ja070451k

Russell, M.J., Hall, A.J., Martin, W., 2010, Serpentinization as a source of energy at the origin of life: Geobiology, 8, 355-371. https:// doi.org/10.1111/j.1472-4669.2010.00249.x

Santosh, M., Arai, T., Maruyama, S., 2017, Hadean Earth and primordial Continents: The cradle of prebiotic life: Geoscience Frontiers, 8, 309-327. https://doi. org/10.1016/j.gsf.2016.07.005

Smith, J.V. 1998, Biochemical evolution. I. Polymerization on internal, organophilic silica surfaces of dealuminated zeolites and feldspars: Proceedings of the National Academy of Sciences, 95, 3370-3375. https://doi.org/10.1073/pnas.95.7.3370

Simoneit, B.R.T., 2004, Prebiotic organic synthesis under hydrothermal conditions: an overview: Advances in Space Research, 33, 88-94. https://doi.org/10.1016/j.asr.2003.05.006

Smithies, D., Hart, E.J., 1960, Radiation chemistry of aqueous formic acid solution. Effect of concentration: Journal of the American Chemical Society, 82, 4775-4779. https:// doi.org/10.1021/ja01503a005

Smyth, J.R., Hazen, R.M., 1973, The Crystal Structures of Forsterite and Hortonolite at Several Temperatures $\mathrm{Up}$ to $900{ }^{\circ} \mathrm{C}$ : American Mineralogist, 58 (7-8), 588-593.

Spandler, C., O’Neill, H.St.C., Kamenetsky, V.S., 2007, Survival times anomalous melt inclusions from element diffusion in olivine and chromite: Nature, 447, 303-306. https:// doi.org/10.1038/nature05759

Spinks, J.W.T., Woods, R.J.,1990, Introduction to radiation chemistry, Third edition. John
Wiley \& Sons Inc, 314-322.

Staudigel, H., 2003, Hydrothermal alteration processes in the oceanic crust: Treatise on Geochemistry, 3, 511-535. https://doi. org/10.1016/B0-08-043751-6/03032-2

Thomas, J.K., 1993, Physical aspects of photochemistry and radiation chemistry of molecules adsorbed on silica, gamma -alumina, zeolites, and clays: Chemical Reviews, 93, 301-320. https://doi. org/10.1021/cr00017a014

Wescott, B.B., Engelder, C.J., 1926, The Catalytic Decomposition of Formic Acid: The Journal of Physical Chemistry, 30, 476-479. https:// doi.org/10.1021/j150262a004

Westall, F., Hickman-Lewis, K., Hinman, N., Gautret, P., Campbell, K.A., Bréhéret, J.G., Foucher, F., Hubert, A., Sorieul, S., Dass, A.V., Kee, T.P., Georgelin, T., Brack, A., 2018, A Hydrothermal sedimentary context for the origin of life: Astrobiology, 18, 259-293. https://doi.org/10.1089/ ast. 2017.1680

Yu, J., Savage, P.E., 1998, Kinetics, catalysis, and reaction engineering: Industrial and Engineering Chemistry Research, 37, 2-10. https://doi.org/10.1021/ie970182e

Zacheis, G.A., Gray, K.A., Kamat, P.V., 1999, Radiation-induced catalysis on oxide surfaces: Degradation of hexachlorobenzene on $\gamma$ irradiated alumina nanoparticles: Journal of Physical Chemistry B, 103, 21422150. https://doi.org/10.1021/jp990211u

Zaia, D. A. M., Pereira, R. D. C., Samulewski, R. B., 2018, Adenine and thymine effect on quartz dissolution at different artificial seawaters. Orbital: The Electronic Journal of Chemistry, 10(6), 446-452. http://dx.doi. org/10.17807/orbital.v10i6.1152

Zhao, Y., Ginsberg, S.B., Kohlstedt, D.L., 2004, Solubility of hydrogen in olivine: dependence on temperature and iron content: Contributions to Mineralogy and Petrology, 147, 155-161. https://doi. org/10.1007/s00410-003-0524-4. 